\title{
Transport Of Particles Across Continental Shelves
}

CA Nittrouer

LD Wright

Virginia Institute of Marine Science

Follow this and additional works at: https://scholarworks.wm.edu/vimsarticles

Part of the Geochemistry Commons, and the Geophysics and Seismology Commons

\section{Recommended Citation}

Nittrouer, CA and Wright, LD, "Transport Of Particles Across Continental Shelves" (1994). VIMS Articles. 1410.

https://scholarworks.wm.edu/vimsarticles/1410

This Article is brought to you for free and open access by W\&M ScholarWorks. It has been accepted for inclusion in VIMS Articles by an authorized administrator of W\&M ScholarWorks. For more information, please contact scholarworks@wm.edu. 


\section{TRANSPORT OF PARTICLES ACROSS CONTINENTAL SHELVES}

\author{
Charles A. Nittrouer \\ Marine Sciences Research Center \\ State University of New York, Stony Brook
}

\author{
L. Donelson Wright \\ Virginia Institute of Marine Science \\ College of William and Mary, Gloucester Point
}

\begin{abstract}
Transport of particulate material across continental shelves is well demonstrated by the distributions on the seabed and in the water column of geological, chemical, or biological components, whose sources are found farther landward or farther seaward. This paper addresses passive (incapable of swimming) particles and their transport across (not necessarily off) continental shelves during high stands of sea level. Among the general factors that influence across-shelf transport are shelf geometry, latitudinal constraints, and the timescale of interest. Research studies have investigated the physical mechanisms of transport and have made quantitative estimates of mass flux across continental shelves. Important mechanisms include wind-driven flows, internal waves, wave-orbital flows, infragravity phenomena, buoyant plumes, and surf zone processes. Most particulate transport occurs in the portion of the water column closest to the seabed. Therefore physical processes are effective where and when they influence the bottom boundary layer, causing shear stresses sufficient to erode and transport particulate material. Biological and geological pro-
\end{abstract}

cesses at the seabed play important roles within the boundary layer. The coupling of hydrodynamic forces from currents and surface gravity waves has a particularly strong influence on across-shelf transport; during storm events, the combined effect can transport particles tens of kilometers seaward. Several important mechanisms can cause bidirectional (seaward and landward) transport, and estimates of the net flux are difficult to obtain. Also, measurements of across-shelf transport are made difficult by the dominance of alongshelf transport. Geological parameters are often the best indicators of net across-shelf transport integrated over time scales longer than a month. For example, fluvially discharged particles with distinct composition commonly accumulate in the midshelf region. Acrossshelf transport of particulate material has important implications for basic and applied oceanographic research (e.g., dispersal of planktonic larvae and particle-reactive pollutants). Continued research is needed to understand the salient mechanisms and to monitor them over a range of timescales.

\section{INTRODUCTION}

The continents are the largest source for most types of particulate material entering the world ocean. The fraction of material that is carried to the ocean beyond continental shelves is dependent on mechanisms that transport particles across shelves. This is the fundamental importance of across-shelf transport, but it also has several corollary considerations. (1) Many of the dissolved components supplied by continents are transformed into particles on shelves (e.g., particlereactive metals, biological nutrients), and therefore the fates of these materials also depend on mechanisms of particulate transport. (2) Mechanisms preventing across-shelf transport (i.e., accumulation of particles on continental shelves) are equally important because they also control the quantity and quality of material delivered to the deeper ocean. (3) Some oceanic mechanisms can transport particles landward. In areas where these mechanisms operate and during periods when they are operating, net transport of par- ticles is toward and possibly into estuaries, lagoons, beaches, or other coastal environments.

The importance and diverse aspects of across-shelf transport for all materials (water, solutes, and particles) have led to much research, and this paper reviews some of the more recent studies. The present synthesis is confined to the following considerations.

1. Discussions focus upon passive particles that consist primarily of inorganic sediments but also include dead organic solid phases. Living organisms are relevant only if they reside on particles (e.g., some bacteria) or are incapable of horizontal or vertical motion (e.g., some planktonic larvae). The flux of water is considered only as the transporting medium for particles. Some dissolved phases are relevant, but only after their transformation to a particulate form.

2. Particulate transport across continental shelves (e.g., toward the shelf break) will be considered. The mechanisms for transport off shelves are not necessarily the same and will not be discussed explicitly.

3. Continental shelves are geologically ephemeral 
features. They do not exist during glacial low stands, or during long periods of high stand where shorelines are able to prograde to the shelf break. In addition, across-shelf transport probably behaves differently during periods of rapid rise or fall of sea level. Discussions will be limited to relatively stable high-stand conditions.

The following sections provide a synthesis of the general considerations for across-shelf transport of particles. Physical processes drive the transport, and most of the mass flux occurs in the bottom boundary layer. The longer-term evidence for the transport is demonstrated from geological observations. Considerations for future research are discussed in the final section.

\section{GLOSSARY OF TECHNICAL TERMS}

Active versus passive continental margins: Active margins are tectonically active in the sense that they are in the immediate vicinity of a convergence (collision) between lithospheric plates or near an active spreading center. Passive margins are relatively inactive tectonically and are distant from spreading or convergence.

Baroclinic: Pertaining to processes that involve pressure gradients related to density differences (stratification) within the water column.

Barotropic: Pertaining to processes that involve pressure gradients related to variations in sea surface elevation.

Bottom boundary layer: The layer of the water column just above the seafloor where flows are significantly retarded by bed friction and where vertical momentum transfers are most intense.

Buoyant plumes: Relatively thin layers of positively and negatively buoyant sediment-laden water issuing from a point source such as a river mouth. Positively buoyant plumes disperse in the surface layer, negatively buoyant plumes disperse over the bed.

Coastal-trapped waves (continental shelf waves): Long-period (several days) oscillations that are topographically trapped near the coast and propagate along the coastal boundary. They propagate poleward along eastern boundaries (i.e., where the land is east of the shelf) and equatorward along western boundaries (i.e., where land is west of the shelf).

Downwelling versus upwelling: Downwelling flows are typically seaward near the bed and thus downslope in the regional shelf-wide sense; they are commonly accompanied by shoreward flows near the surface. Upwelling flows are shoreward and upslope near the bed and are often accompanied by seaward transports in the surface layer.

Edge waves: Gravity waves that are trapped by refraction over the inner shelf and in the surf zone.
They commonly have infragravity frequencies (periods between 20 and $300 \mathrm{~s}$ ).

Epicontinental versus pericontinental shelves: Epicontinental shelves are semienclosed and lie partially within the confines of continents (e.g., the Yellow Sea). Pericontinental shelves are those off open coasts (e.g., the Atlantic or Pacific coast of North America).

Gravity waves: As used in this review, gravity waves imply water waves (such as wind-induced surface waves or tides) in which gravity provides the restoring force that sustains wave propagation. Gravity waves may be either barotropic (surface) or baroclinic (internal).

Geostrophic currents: Steady currents that are sustained by a balance between a pressure gradient force and the Coriolis force (e.g., the Gulf Stream).

Groupy waves: Wind-driven surface gravity waves in nature commonly arrive at any point as a succession of alternating packets or "groups" of high and low waves. The resulting wave train of varying wave amplitude is referred to as groupy.

Hydraulic roughness: The nominal height of the bottom roughness elements in terms of their effects on near-bottom flows. The greater the hydraulic roughness length, the higher will be the elevation above the bed at which friction causes the current velocity to go to zero.

Infragravity waves: Surface gravity waves with oscillation frequencies lower than those of the windgenerated surface waves. The periods of infragravity waves are in the range of 30 to $300 \mathrm{~s}$. Infragravity waves have multiple origins: edge waves, leaky mode standing waves, or groups of wind-generated surface waves.

Leaky mode standing waves: Standing waves that are not trapped near the coast. In contrast to edge waves, reflected energy associated with leaky mode standing waves is radiated ("leaked") back to sea. Typically, these waves have infragravity frequencies.

Radiation stress: An excess flux of momentum (associated with surface gravity waves) in the direction of wave propagation.

Shear stress: A friction force per unit area. As applied in the context of this paper, shear stress refers to a friction force per unit area of seafloor induced by the motion of water above the bed.

Wave-current boundary layers: Bottom boundary layers within which wave oscillatory flows and mean currents interact very close to the bed $(\sim 10 \mathrm{~cm})$ to enhance the total shear stress and rate of momentum transfer.

\section{FACTORS DISTINGUISHING SHELVES}

Numerous factors distinguish particulate transport across continental shelves. Some of these result from the combination of physical processes operating for a 


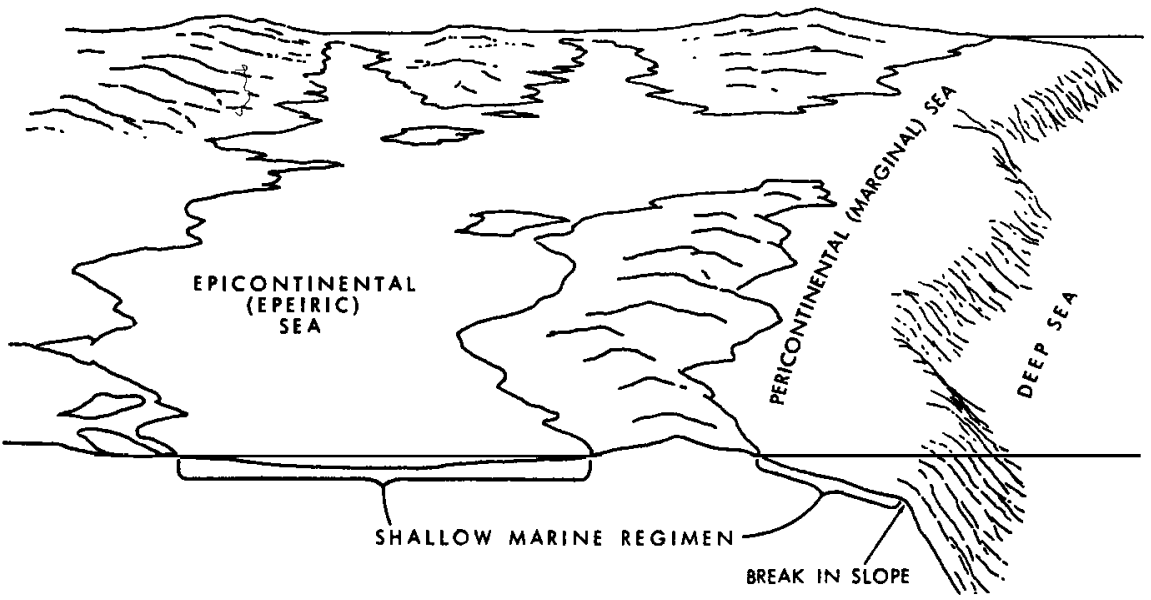

Figure 1. Continental shelves today (and through geologic time) fall into two broad categories. Epicontinental shelves are semienclosed basins extending into the interiors of continents (e.g., the Yellow Sea, Adriatic Sea, and North Sea). Pericontinental shelves are marginal to continents and are common today because of the Holocene rise in sea level (during approximately the past 17,000 years). From Heckel [1972].

particular shelf area (e.g., internal waves, buoyant plumes) as discussed in the next section. Other factors are more general characteristics of the shelves and are discussed below.

\section{Geometry}

Continental shelves fall into two broad categories (Figure 1 [Heckel, 1972]). Pericontinental shelves are marginal to continents, and are most common today. They are ubiquitous because the Holocene rise in sea level (beginning about 17,000 years ago) flooded the land surface fringing continents. Epicontinental shelves are semienclosed basins that extend into continental interiors at a number of locations around the world (e.g., the Yellow, Adriatic, North, Baltic, and Arabian seas). In the geologic past, epicontinental shelves were more common, depending on the history of vertical motions of sea level (eustatic fluctuations) and land surfaces (tectonic activity). Epicontinental shelves have a three-dimensional geometry that makes transport processes more complex and the question of across-shelf transport more confused (what directions are along shelf and across shelf?).
Other sections of this paper demonstrate that the width, depth, and steepness of a shelf affect energy (e.g., sediment resuspension by surface waves or energy expenditure by tidal friction) and material (e.g., entrapment of sediment) aspects of across-shelf transport. Broad shelves are typically found in association with continental margins that are tectonically passive and are relatively shallow $(\sim 100 \mathrm{~m}$ or less at shelf break, e.g., east coast of North America) [Inman and Nordstrom, 1971]. Narrow shelves are the common result of collisions between oceanic and continental crust (active margins, e.g., west coast of South America). Generally, these shelves are also deeper $(>100 \mathrm{~m}$ at shelf break) and therefore steeper.

The shapes of landward and seaward boundaries have a significant effect on particulate transport across continental shelves (Figure 2). Protrusions seaward from the shoreline (capes, headlands) can redirect along-shelf flow and cause across-shelf transport (e.g., near Cape Hatteras [Pietrafesa, 1983] or near rocky headlands [Cacchione and Drake, 1990]). Similarly, depressions can extend landward from the shelf break as gentle shelf valleys or dramatic submarine canyons,

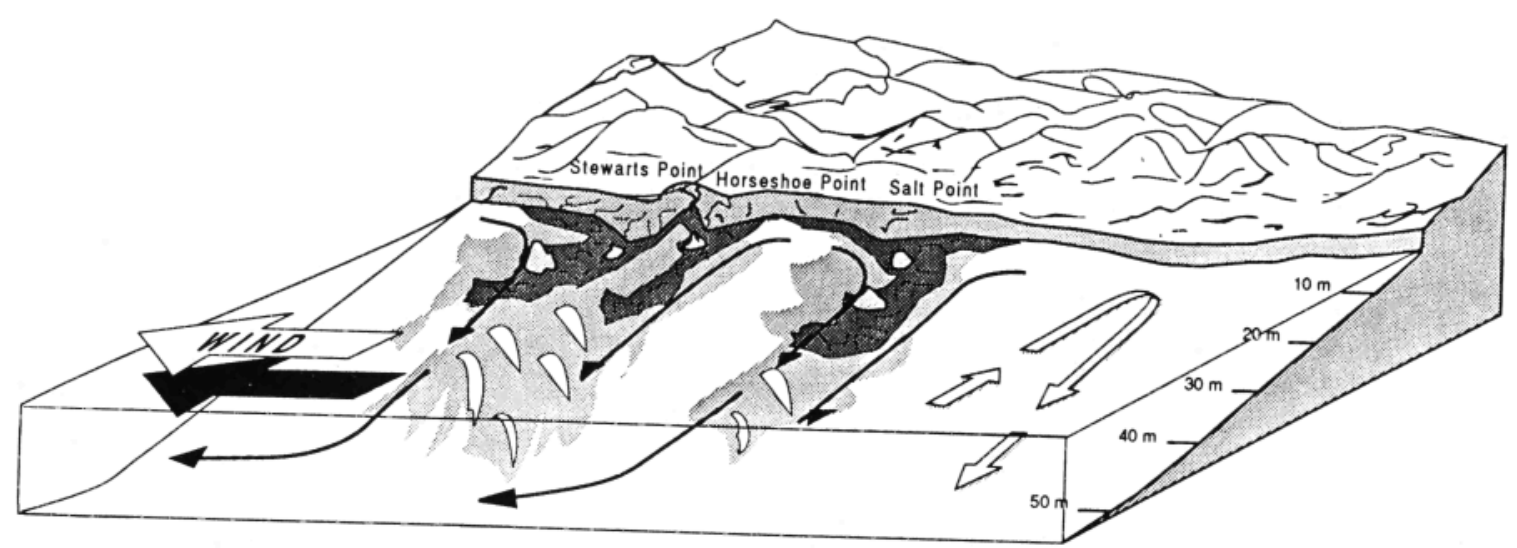

Figure 2. Schematic of the northern California shelf, showing the effects of shoreline promontories that steer sediment transport seaward. This mechanism is aided by landward surface currents that downwell to cause seaward bottom flow. From Cacchione and Drake [1990] (copyright $\mathbb{C} 1990$ by John Wiley, reprinted by permission of John Wiley \& Sons, Inc.). 


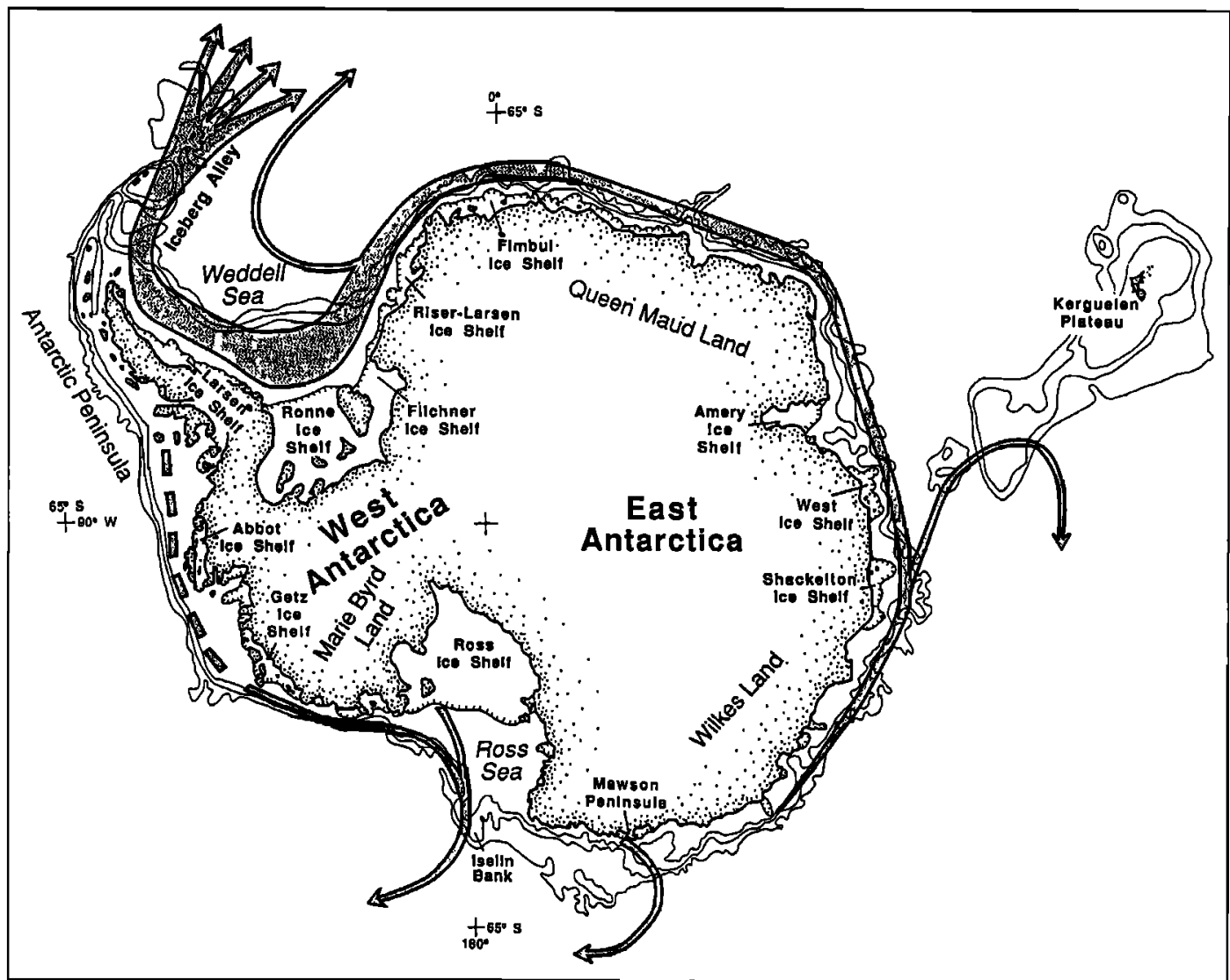

Figure 3. General paths for iceberg drift surrounding the Antarctic continent. These icebergs can carry significant amounts of particulate material, which is released as the icebergs melt. Typical trajectories are along shelf (anticyclonic relative to the continent), but at several points the icebergs cross the shelf and head seaward. From Reid and Anderson [1990] (reprinted by permission).

and these features can act as conduits for particle flux (e.g., Hudson shelf valley [Freeland et al., 1981; Vincent et al., 1981], Lacaze-Duthiers Canyon [Monaco et al., 1990], Nazare Canyon [Dias and Nittrouer, 1984], Quinault Canyon [Carson et al., 1986], and Zaire Canyon [Eisma and Kalf, 1984; Pak et al., 1984]).

\section{Latitude}

Through a diversity of processes, the latitudinal location of a site can affect across-shelf transport. The most obvious examples are at the extremes: polar and tropical settings. Iceberg rafting provides a mechanism for seaward transport of coarse sediment (sand to boulder size) released by calving glaciers [Anderson et al., 1984]. Sea ice (frozen seawater) can acquire sediment nearshore, where the seabed is frozen together with seawater (fast ice) [Clark and Hanson, 1983]. Sediment-laden icebergs and sea ice float with prevailing surface currents (Figure 3), melting and dropping sediment hundreds of kilometers seaward of their origins [Jacobs, 1989; Reid and Anderson, 1990]. In some cases, large floating ice sheets (e.g., the Ross Ice Shelf) release their sediment load beneath the sheet; the sediment is then transported by ambient currents, forming seaward prograding subice deltas [Alley et al.,
1989]. In Arctic settings, sea ice cover inhibits acrossshelf transport by limiting the fetch of winds that generate surface gravity waves during the summer. The fetch is generally eliminated during the winter as sea ice welds to the shoreline [Hill and Nadeau, 1989]. This is significant because seasonal rivers and meltwater streams supply much sediment to the nearshore, and it is not carried much farther seaward (e.g., the Canadian Beaufort shelf [Hill et al., 1991]). Similar considerations are not relevant in Antarctic settings because the entire shelf is below the wave base $(>200$ $\mathrm{m}$, due to continental subsidence from ice sheets) and surficial meltwater does not occur.

Low-latitude settings can reveal unique mechanisms for across-shelf transport due to factors of physical transport and particle source. Trade winds represent a nearly continuous source of energy (with some fluctuations of intensity and direction) for production of surface gravity waves and currents. The waves can resuspend and transport sediment [Harris, 1991; Pujos and Javelaud, 1991]. However, the generating winds also drive water against the coast, sloping the water surface, and creating barotropic currents with a predominant along-shelf transport direction (e.g., the Java Sea [Hoekstra et al., 1989], the Gulf of Papua [Wright, 1989], or northeast South America [Geyer et 
al., 1991]). Tropical seabeds distant from dispersal systems of rivers usually contain deposits of calcium carbonate debris produced by marine organisms (e.g., Halimeda algae, coral). The input of this material is unique, because the source (biological production) is distributed across the shelf. Transport landward can occur into beach and tidal flat settings [Shinn, 1983; Inden and Moore, 1983]. Transport seaward is easy and permanent because carbonate shelves typically accrete as relatively narrow features that descend steeply beyond their seaward edge. Waves and currents can cause off-shelf transport [Hine et al., 1981], and topographic depressions (chutes and canyons) aid the removal of sediment [Moore et al., 1976; Hoskin et al., 1986].

\section{Timescales}

Across-shelf particulate transport is dependent on the timescale of interest. At the short-term extreme, transport direction commonly reverses over the period of a surface gravity wave (seconds). Even the net transport from waves (averaged over many periods) can reverse between fair weather and storm conditions [Swift et al., 1985]. Tidal processes are another source of temporal variability that can cause speed and direction of transport to fluctuate on timescales of hours. Further, the net effect of tidal currents can vary over fortnightly scales with spring-neap modulation of the tides [Geyer et al., 1991; Kineke et al., 1991]. On seasonal time scales, particles transported seaward in river plumes during the seasonal peak discharge can be returned landward in bottom waters during the rest of the year as part of estuarine circulation [Meade, 1969]. A catastrophic event (e.g., with recurrence interval > 10 years) such as an extreme flood of a river [Drake et al., 1972; Borgeld, 1985] or major storm (e.g., hurricane [Morton, 1981; Snedden and Nummedal, 1991]) can significantly affect the average across-shelf transport. At the long-term extreme, sea level fluctuations over millennia influence across-shelf transport, but these are beyond the scope of the present discussion.

The history of most particle movement involves short periods when shear stress is sufficient for erosion and transport, and longer quiescent periods when particles rest on the bottom. During the quiescent periods, the particles can be buried or mixed downward by bioturbation and thereby removed from the transport system. The particles are then trapped at some location on the shelf. The factors influencing the outcome are rates of particle accumulation and biological mixing, the frequency of erosion, and depths of mixing and erosion [Nittrouer and Sternberg, 1981]. Particles are not all the same in regard to size, shape, and composition. Physical erosion and transport and biological mixing processes may selectively bury certain particles, causing particles to be sorted during their journey across the shelf [Nittrouer and Sternberg, 1981; Kachel and Smith, 1986].

\section{Along-Shelf Transport}

For most locations the magnitude of along-shelf particulate transport is much greater than the corresponding across-shelf component (e.g., for the U.S. Mid-Atlantic Bight [Butman et al., 1979] or for the Washington shelf [Smith and Hopkins, 1972; Sternberg and McManus, 1972; Kachel and Smith, 1989]). This observation has much relevance to individual shelves, affecting the fundamental mechanisms for particle transport as well as the measurement of transport. Where along-shelf transport is the overwhelming process, across-shelf transport can be dominated by considerations of geometry, such as capes or canyons, which divert flow across the shelf before more subtle transport mechanisms become effective. Across-shelf fluxes must approach zero nearshore (away from a river mouth or estuary); therefore across-shelf gradients in transport are normally greater than along-shelf gradients. This is particularly true off straight coasts and over the inner shelf. The distinct difference in magnitude between strong along-shelf and weak across-shelf transports makes across-shelf particle flux difficult to resolve.

\section{PHYSICAL PROCESSES}

Particulate transport in both the along-shelf and across-shelf dimensions is driven almost entirely by water motions. Understanding the physical oceanography of the shelf is thus an essential prerequisite to understanding the more complicated questions of across-shelf particulate transport. Over the past 5 years, several reviews and workshops have summarized the state of knowledge of shelf physical oceanography. Brink [1987] offered a succinct review of coastal ocean circulation including references to the state of the art (as of 1987) on boundary layer processes, coastal-trapped waves, and upwelling. More recently, Huyer [1990] reviewed theoretical and empirical knowledge on currents, including upwelling and downwelling flows, over the continental shelf. The roles of internal waves and other baroclinic processes on continental shelves are treated in a special volume edited by Mooers [1986]. The intense but relatively small scale surf zone processes that operate in the innermost region of the margin are summarized in the reviews and general treatises by Battjes [1988], Massel [1989], and Battjes et al. [1990]. A workshop report by Holman et al. [1990] details the state of the art and future research needs in nearshore processes research. Two important workshop reports covering multiple aspects of coastal oceanography are those prepared by the Coastal Physical Oceanography (CoPO) [CoPO Steering Committee, 1989] and Coastal Ocean Processes (CoOP) [Brink et al., 1990, 1992] steering committees.

The flow regimes of continental shelves are not at 


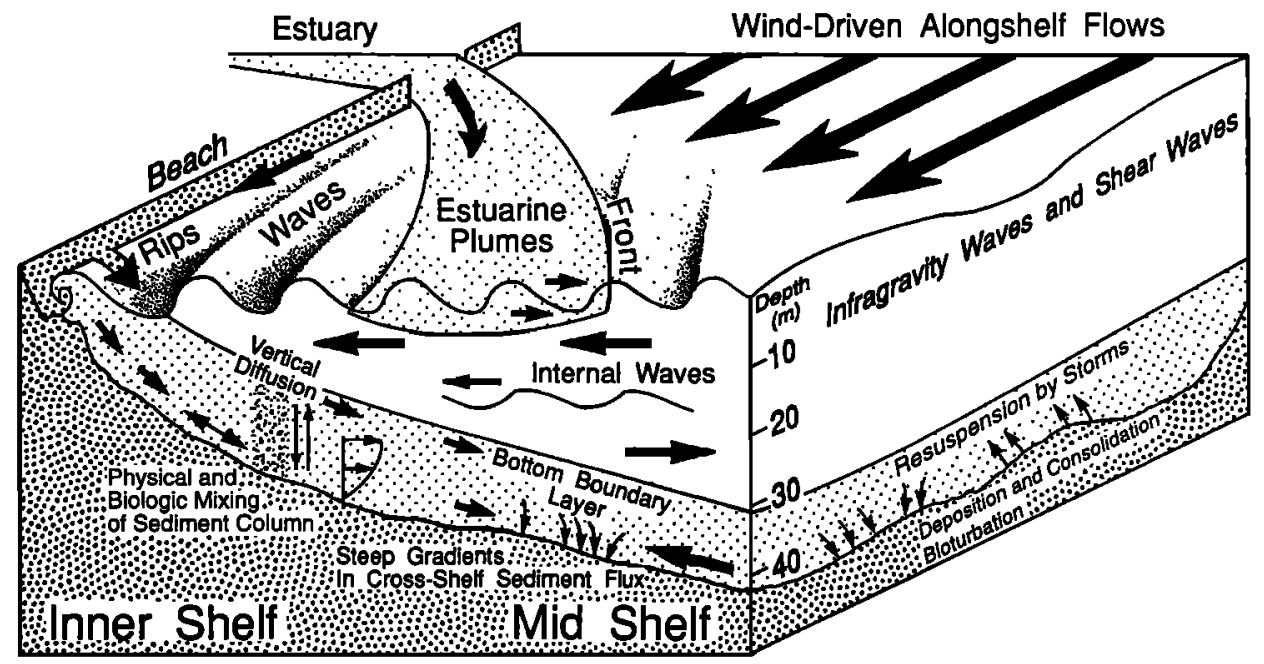

Figure 4. Conceptual diagram illustrating the major physical processes responsible for across-shelf particulate transport.

all uniform from the shore to the shelf break but vary appreciably as water depth changes. Some of the transport phenomena governing across-shelf fluxes of particles are illustrated in Figure 4. Not only do velocities change across the shelf, but so too do the relative roles played by various types of flows. For convenience, the shelf is divided into regimes of the outer shelf, the middle shelf, the inner shelf, and the surf zone (Figure 5). Over the outer shelf, geostrophic flows are most important, frictional forces are small, and wave-induced bottom agitation is minimal most of the time. In contrast, the inner shelf is a frictionally dominated realm in which surface and bottom boundary layers overlap and may occupy the entire water column. Breaking waves are the dominant source of flows within the surf zone. The midshelf region is generally characterized by relatively steep acrossshelf transitions in flow regime and by a seaward decrease in the frequency and intensity of bed agitation.

This review will focus on the specific mechanisms that contribute the most to across-shelf particulate transport (Figure 4). Specifically, these are (1) winddriven upwelling and downwelling flows, (2) internal waves, (3) wave-orbital flows, (4) infragravity oscillations, (5) buoyant plumes (positive and negative), and (6) surf zone (wave driven) processes.

In simple cases where stratification is neglected and flows are depth averaged and time averaged over several wave cycles, the along-shelf $(y)$ and across-shelf (x) momentum balances are [e.g., Brink, 1987; Lentz et al., 1990]

$$
\begin{aligned}
& \frac{\partial v}{\partial t}+\mathrm{NL}+f u=-g \frac{\partial \eta}{\partial y}+\frac{1}{\rho h}\left[\tau_{\mathrm{s} y}-\tau_{\mathrm{b} y}+\frac{\partial S_{x y}}{\partial x}\right] \\
& \frac{\partial u}{\partial t}+\mathrm{NL}-f v=-g \frac{\partial \eta}{\partial x}+\frac{1}{\rho h}\left[\tau_{\mathrm{s} x}-\tau_{\mathrm{b} x}+\frac{\partial S_{x x}}{\partial x}\right]
\end{aligned}
$$

where $v$ and $u$ are respectively the along-shelf and across-shelf components of flow, $t$ is time, NL desig-

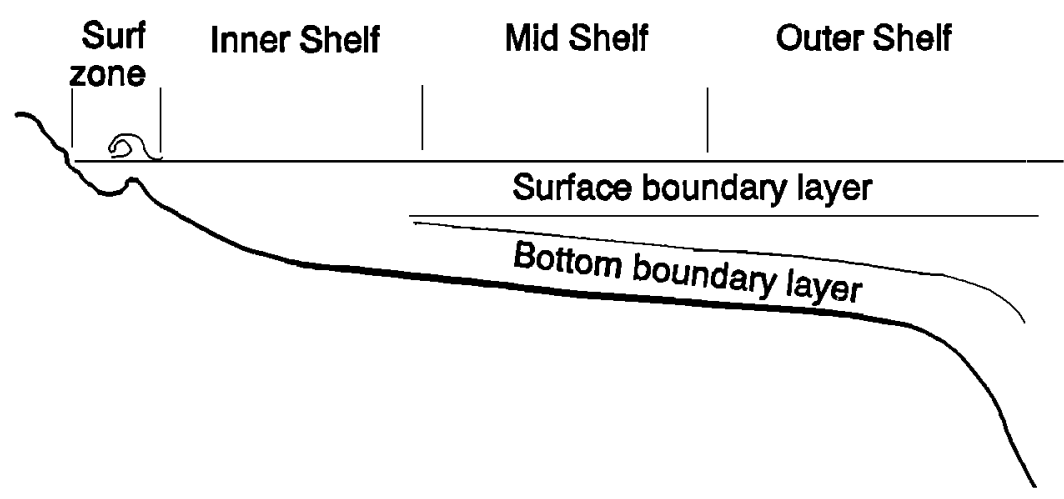

Figure 5. Spatial relationships of the major subregions of the continental shelf. Note that the surface and bottom boundary layers merge over the inner shelf. 
nates the relevant nonlinear terms, $f$ is Coriolis frequency, $g$ is acceleration of gravity, $\rho$ is water density, $h$ is water depth, $\eta$ is sea surface elevation, $\tau_{\mathrm{s}}$ and $\tau_{\mathrm{b}}$ are surface and bottom shear stresses with subscripts $y$ and $x$ designating the along-shelf and across-shelf components, $S_{x y}$ is the oblique component of surface gravity wave radiation stress [Longuet-Higgins and Stewart, 1964], and $S_{x x}$ is the component in the direction of wave propagation that is assumed here to be shore normal. The radiation stresses are proportional to the square of wave height, $\boldsymbol{H}$. Over the outer shelf and midshelf regions, the contributions of the radiation stress terms are negligible and those of the bed stress and nonlinear terms are very small [e.g., Huyer, 1990]. Over the inner shelf, radiation stress terms remain small but are not negligible, bed stress and nonlinear terms are important, and $f u$ becomes negligible as the shore is approached. Radiation stress gradients strongly dominate surf zone circulation [Battjes et al., 1990].

In fact, flows are not vertically uniform. If they were, there would be no net across-shelf transport of water or particles over the inner shelf, because the vertical average $u$ must vanish over the inner shelf and nearshore (at least so far as $u$ is averaged in $y$ and $t$ ). However, net particle transports are effected by the fact that flows near the bed are often in the opposite direction to flows at the surface or at middepth. Vertical segregations of flow over the shelf, and horizontal and vertical segregations in the surf zone, are thus crucial to across-shelf fluxes.

\section{Wind-Driven Flows}

Surface and bottom mixed layers over the outer shelf are often distinct and separated by a stratified interior (Figure 5; also Huyer, [1990]). In such cases, seaward Ekman transport in the surface layer, driven by along-shelf winds with the coast to the left (northern hemisphere), is accompanied by upwelling at varying depths [Huyer, 1990; Smith, 1981]. With winds in the opposite direction, surface transport is landward, and seaward downwelling flows prevail at depth. Smith [1981] observed upwelling flows over $10 \mathrm{~cm} \mathrm{~s}^{-1}$ to be dominant within the bottom layer of the outer shelf off northwest Africa but to be most intense at middepth off Peru and Oregon. Results from the outer shelf of the Middle Atlantic Bight obtained via the first Shelf Edge Exchange Processes (SEEP-I) field study showed that net transports were seaward in the surface and bottom layers; landward flow of slope water took place at middepth [Walsh et al., 1988]. Lyne et al. [1990a] obtained long-term near-bottom current measurements from six stations in the 60- to 80-m-depth region of the southern Georges Bank and the Middle Atlantic Bight. The results revealed both landward and seaward mean flows with speeds of the order of $10 \mathrm{~cm}$ $\mathrm{s}^{-1}$. Vertical velocity profiles obtained from the midshelf region off northern California during the first Coastal Ocean Dynamics Experiment (CODE) showed bidirectional across-shelf flow speeds of up to $4 \mathrm{~cm} \mathrm{~s}^{-1}$ at all depths [Lentz et al., 1990]. In that data set, seaward flows at a depth of $4 \mathrm{~m}$ were accompanied by landward flows at depths of 11,23 , and $27 \mathrm{~m}$.

Complex patterns of across-shelf particulate transport have been observed for upwelling systems [Pak and Zaneveld, 1977; Drake and Cacchione, 1987] because water motions are distinctly three dimensional, involving vertical as well as across- and along-shelf flows. During periods of equatorward winds off northern California, upwelling of nutrient-rich water increases primary productivity, and biogenic particles spread seaward with surface waters. With relaxation of the winds, upwelled water sinks and returns seaward along the bottom. The bottom nepheloid layer expands with a combination of biogenic and lithogenic particles, and the seaward motion is superimposed on a poleward flow.

The thicknesses of the surface and bottom mixed layers are important in determining the vertical portions of the water column influenced by across-shelf fluxes. Lentz and Trowbridge [1991] showed that the bottom mixed layer on the outer shelf off northern California typically varies in thickness from 5 to $15 \mathrm{~m}$ but can occasionally attain a thickness of $50 \mathrm{~m}$. They note that off Oregon, northern California, and Peru the mixed-layer thickness increases with increasing water depth up to a maximum thickness of one half the water depth. For the northern California case, Lentz and Trowbridge [1991] found that the greatest thicknesses occurred during downslope near-bottom flows.

Surface and bottom layers merge over the middle and inner shelf (Figure 5) and the interior region disappears [Mitchum and Clarke, 1986; Huyer, 1990]. On the inner shelf, the entire water column is often frictionally dominated by a combination of $\tau_{s}$ and $\tau_{b}$. Field observations of near-bottom flows on the inner shelf of the Middle Atlantic Bight have been made by Wright et al. [1986, 1991a] during northeasterly storms, when wind stress created both southerly and landward setting surface transports and resulted in high-standing water being trapped against the shore. Offshore flows within the lower meter of the water column attained speeds of up to $20 \mathrm{~cm} \mathrm{~s}^{-1}$ [Wright et al., 1986, 1991a]. During the extreme "Halloween" storm of October 1991, near-bottom (125-cm elevation) flows over the 13-m isobath attained along-shelf (southerly) and seaward velocities of $50 \mathrm{~cm} \mathrm{~s}^{-1}$ and $10 \mathrm{~cm} \mathrm{~s}^{-1}$, respectively [Madsen et al., 1993]. However, shortly after the wind shifted to northwest, resulting in a seaward wind stress component, the across-shelf flows reversed and set toward shore, causing shoreward sediment flux (Figure 6 [Wright, 1993]).

\section{Internal Waves}

Internal waves, particularly internal tides, propagating shoreward over the shelf are an important mechanism for the landward transport of larvae and 


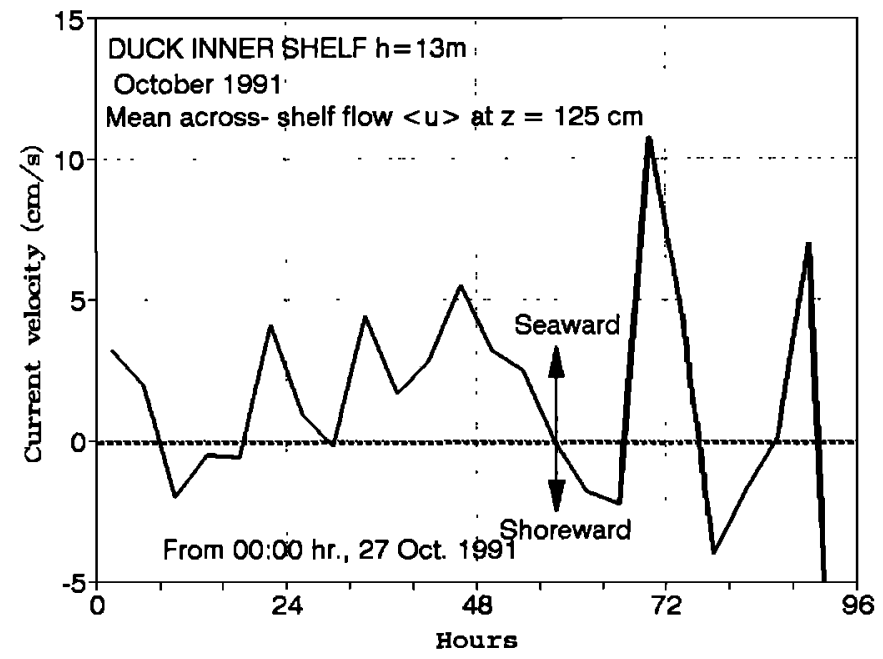

Figure 6. Burst-averaged across-shelf components of flow measured on the inner continental shelf at a water depth of $13 \mathrm{~m}$ off Duck, North Carolina, during the severe extratropical storm of October 1991. The flows shown were at an elevation of $125 \mathrm{~cm}$ above the bed and were measured with a Marsh-McBirney electromagnetic current meter (3.8-cm sphere). Sampling frequency was $1 \mathrm{~Hz}$, and burst duration was $17 \mathrm{~min}$.

other particulates [Shanks, 1983, 1988; Shanks and Wright, 1987; Pineda, 1991]. These internal waves, with diurnal or semidiurnal frequencies, are typically generated near the shelf break; first-mode internal tides are usually dominant over shelves [Baines, 1986; Largier, 1987]. Because flows associated with internal tides are oscillatory, both landward and seaward flows occur, and the actual direction of particle transport will depend on the level within the water column that the particles occupy. Larvae tend to remain at a constant depth [e.g., Forward, 1990], and this can cause them to remain within the landward flows of both the crests and the troughs of first-mode internal waves. As internal tides shoal over the shelf with progressively decreasing water depth, they become asymmetrical and ultimately break [Kao et al., 1985; Holloway, 1987; Helfrich, 1992]. Pineda [1991] reports large temperature fluctuations at the end of the Scripps pier (southern California) that he attributes to internal tidal bores that surge landward after breaking over the inner shelf. Pineda [1991] further suggests that these bores contribute to the landward transport of planktonic larvae all the way to the surf zone. The likely importance of shoaling internal waves in suspending as well as transporting sediment was reported 2 decades ago by Cacchione and Southard [1974].

For the outer shelf of the Celtic Sea, internal waves have been observed to propagate both onshelf and offshelf [Heathershaw, 1985]. Flow velocities associated with the internal waves are $30-40 \mathrm{~cm} \mathrm{~s}^{-1}$ and are superimposed on other local currents. Similarly, large currents $\left(20 \mathrm{~cm} \mathrm{~s}^{-1}\right)$ from internal waves have been observed on the New Jersey shelf [Butman et al.,
1979], especially during stratified conditions in the summer. These velocities are sufficient to significantly affect across-shelf transport rates. Observations of internal waves on the eastern Canadian continental shelf (Sable Island Bank and Grand Banks) suggest that net sediment fluxes are seaward [Boczar-Karakiewicz et al., 1991].

\section{Wave-Orbital Flows}

In a later section of this review, simple back-andforth motions from wave-induced near-bottom flows are discussed along with their contributions to bed shear stress and sediment entrainment. In addition, nonlinearities cause orbital velocity asymmetries and net mass transports that increase with increasing wave amplitude and decreasing water depth. Fenton [1990] describes current theory of nonlinear waves including higher-order Stokes theory, cnoidal wave theory, and Fourier approximation methods. Empirical models for across-shelf sediment transport by asymmetrical wave-orbital velocities are discussed by Krause and Horikawa [1990], among others. The idea that orbital asymmetries dominate the landward transport of sand over the middle and inner shelf is prevalent among many geologists and engineers [e.g., Wells, 1967; Hallermeier, 1981; Swift et al., 1985]. However, the presence of wave ripples can reverse the direction of nearbottom particle transports [Krause and Horikawa, 1990; Nielsen, 1979, 1992]. In addition, Trowbridge and Madsen [1984a, b] show that mass transport in the wave boundary layer can be in either direction. Dean and Perlin [1986] conclude that fairly elaborate hybrid models must be used to estimate bed stress under asymmetrical waves. Most recently, cospectral analyses applied to field data of simultaneous velocity and time series of suspended sediment concentration show that wave asymmetries do in fact cause onshore transports inside the surf zone [Osborne and Greenwood, $1992 a, b]$. Outside the surf zone, wave-induced transport may be in either direction [Wright et al., 1991a].

\section{Infragravity Phenomena}

Waves in nature are typically "groupy" in the sense that they come in alternating sets of high and low waves. Longuet-Higgins and Stewart [1962, 1964] show that a second-order, group-forced long wave results from the temporal variations in radiation stress, $S_{x x}(t)$, that are associated with a groupy wave train. The time-varying water surface elevation, $\eta^{\prime}(t)$, of the group-bound long wave is described by

$$
\eta^{\prime}(t)=-\frac{1}{\rho}\left[\frac{S_{x x}(t)}{g h-C_{\mathrm{g}}^{2}}\right]
$$

where $C_{\mathrm{g}}$ is wave group velocity. Equation (3) predicts a long-wave trough with its attendant seaward setting flows to coincide with packets of high waves; the 


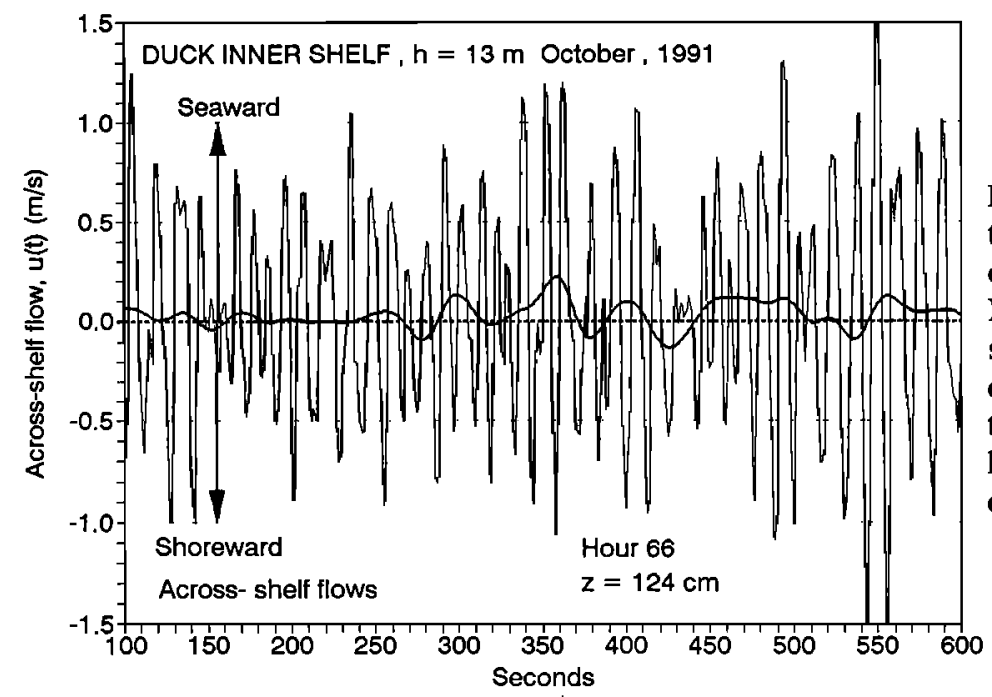

Figure 7. Example of instantaneous and low-pass-filtered time series of across-shelf flows, $u(t)$, at a depth of $13 \mathrm{~m}$ (measured $124 \mathrm{~cm}$ above seabed) off Duck, North Carolina, within a burst during the extratropical storm of October 1991. Note the infragravity frequency intensifications of seaward flows in conjunction with groups of larger waves (as expressed by higher instantaneous orbital velocities). Based on data discussed by Wright et al. [1994]. long-wave crest occurs in association with the small wave sets. Field observations obtained over the inner shelf during a severe storm by Wright et al. [1994] show seaward flows to experience amplifications greater than $10 \mathrm{~cm} \mathrm{~s}^{-1}$ under packets of high waves (Figure 7).

The interactions, within the bottom boundary layer, of the long wave with the groupy incident waves provide a potential process of seaward sediment transport over the inner shelf and midshelf regions and over the outer shelf during severe storms [Shi and Larsen, 1984; Dean and Perlin, 1986]. Field measurements of cospectra for across-shore sediment fluxes in the nearshore zone reveal landward transports to be related to incident waves with infragravity motions contributing primarily to seaward fluxes [Osborne and Greenwood, $1992 a, b]$. Wright et al. [1991a] also found infragravity oscillations to make significant contributions to across-shelf transport of suspended sediment over the inner shelf (8-m depth). However, the associated fluxes were just as often landward as seaward. This result was likely attributable to the fact that over the inner shelf and particularly in proximity to the surf zone, infragravity motions other than simple groupbound long waves are present and complicate the across-shelf flows at infragravity frequencies.

Recent studies show that the infragravity motions that commonly dominate the surf zone and are significant over the inner shelf consist of a combination of edge waves (trapped nearshore) and leaky mode standing waves in which the reflected infragravity energy is radiated seaward [Huntley et al., 1981; Oltman-Shay and Guza, 1987]. Over the inner shelf, edge wave and leaky mode oscillations coexist with the group-forced long waves [Oltman-Shay, 1991; Okihiro et al., 1991]. The field-based study by Okihiro et al. [1991] indicated that $50-75 \%$ of the infragravity energy at a depth of 10 $\mathrm{m}$ was related to group-bound long waves. List [1992] has developed a finite-difference model that predicts the characteristics of long waves in the nearshore region, considering the combined effects of shallowwater group-bound long waves and long waves generated by a time-varying break point. List [1992] concludes that the group-bound long waves are amplified within the surf zone before being reflected from the shore. The implications are that infragravity motions have multiple origins and thus that all transports at infragravity frequency need not necessarily be in any one preferred direction. Future studies are needed to ascertain the importance of infragravity "climate" in controlling the direction of across-shelf transport.

\section{Buoyant Plumes}

Positively and negatively buoyant plumes contribute to surface and near-bottom seaward transports, respectively, of particles across shelves. Characteristically, both plume types are sharply bounded offshore by fronts [Simpson and James, 1986; Garvine, 1987]. The lowered relative densities of positively buoyant (hypopycnal) plumes are attributable in most instances to low-salinity water issuing from rivers and estuaries [e.g., Garvine, 1982]. Negatively buoyant (hyperpycnal) plumes result from intense cooling of coastal water (e.g., by cold air outbreaks); by brine extrusion from freezing sea ice; and by high suspended sediment concentrations (e.g., turbidity currents and related phenomena; see review by Seymour [1990]).

Positively buoyant surface plumes issuing from rivers and estuaries are major sources of buoyancy and sediment to the coastal ocean. Milliman and Meade [1983] report that about $33 \times 10^{3} \mathrm{~km}^{3}$ of fresh water enters the sea annually from rivers. In many cases these plumes reach no farther than the inner or middle shelf before being carried parallel to the coast (e.g., the Amazon shelf [Curtin, 1986; Geyer et al., 1991]). In other cases (e.g., the Gulf of Alaska [Royer, 1982]) they occupy the entire shelf. Chao [1988] developed a model that predicts the behavior and offshore reach of river-forced estuarine plumes over sloping and flat shelves. Chao classifies plumes on the basis of a den- 
simetric Froude number (a dimensionless ratio of inertia relative to buoyancy) and the rate of dissipation. Model applications indicate that over sloping shelves, the seaward extent of the plume is reduced by vorticity. Over flat shelves the plumes can extend farther seaward.

Negative buoyancy is responsible for the highly energetic, autosuspending turbidity currents that transport large quantities of sediment to the base of the continental margin via submarine canyons. Seymour [1990] offers an up-to-date review of these phenomena, which includes field evidence that this mode of acrossshelf transport also may operate over the inner shelf and need not be confined by canyons. Wright et al. [1986, 1991a] also found evidence that negative buoyancy may contribute significantly to across-shelf sediment transport on the inner shelf during storms, when waves maintain high suspended sediment concentrations in the bottom layer of the water column. Negatively buoyant river plumes, though comparatively rare, occur off the mouths of rivers carrying unusually high suspended-sediment loads. The Huanghe (Yellow River) is a prime example. Wright et al. [1990] concluded that the across-shelf dispersal of Huanghe sediments is dominated by negatively buoyant underflows. Early extinction of those underflows significantly constrains transport and results in most of the sediment being deposited near the river mouth.

\section{Surf Zone Processes}

Although the surf zone occupies only a very small fraction of the total shelf width, the transport processes that operate there are extremely intense and therefore deserve mention. In contrast to other shelf environments, the surf zone is severely constrained laterally, and geostrophic effects are negligible. Circulation is driven almost exclusively by forces resulting from the dissipation of breaking waves (e.g., by $\partial S_{x y} / \partial x$ and $\partial S_{x x} / \partial x$ [Battjes et al., 1990; Massel, 1989]. The surf zone alongshore currents and threedimensional rip currents that result from these gradients typically attain speeds well in excess of $1 \mathrm{~m} \mathrm{~s}^{-1}$ [e.g., Massel, 1989]. In addition, vertically segregated across-shore flows, with landward transport in the surface layer and seaward flow in a near-bottom "undertow," have been widely observed and modeled [e.g., Wright et al., 1982; Svendsen, 1984; Roelvink and Stive, 1988]. Although these flows are confined largely to the region landward of the break point, large storm-generated rips have been observed to extend well beyond the surf zone [Cowell, 1986].

The dissipation of wave energy across surf zones is accompanied by the growth of energy at infragravity $(0.033-0.003 \mathrm{~Hz})$ frequencies. These energetically dominant infragravity oscillations have the form of trapped mode edge waves and leaky mode standing waves [Guza and Thornton, 1985]. Field observations in storm-driven surf zones show that suspended sedi- ment transport associated with infragravity motions can be 3 to 4 times larger than that associated with incident waves [Beach and Sternberg, 1988]. Furthermore, cospectra of time series for across-shore sediment concentration and fluid velocity indicate that whereas incident waves are the major contributors to landward transport, infragravity flows cause predominantly seaward transport [Osborne and Greenwood, $1992 a, b]$. In addition to the trapped mode and leaky mode infragravity waves, low-frequency (far infragravity; frequency $<0.01 \mathrm{~Hz}$ ) oscillations have recently been observed and attributed to shear instabilities in the alongshore current [Dodd et al., 1992]. The contribution that these waves make to across-shore transport is not yet clear.

\section{BOTTOM BOUNDARY LAYER PROCESSES}

Processes that determine bed shear stress $\tau$ influence sediment transport in two ways: (1) they determine the bottom drag sensed by the mean flows and hence the near-bottom velocity profile in the region where particle concentrations are highest, and (2) they determine the skin friction applied to sediment particles and thus govern the suspension of particles. Over the continental shelf, bottom boundary layer processes typically involve interactions among currents, waves, bed micromorphology, and sediment suspension and transport. The interactions are complex and nonlinear. Fortunately, substantial progress has been made in recent years in understanding all of the aforementioned aspects of the problem. Recent reviews of the shelf bottom boundary layer and sediment transport processes are offered by Grant and Madsen [1986], Cacchione and Drake [1990], Sleath [1990], and Soulsby [1990].

\section{Wave-Current Boundary Layer Models}

On the shelf, wind-generated waves are generally present and are responsible for the existence (in the bed layer of the inner shelf under most conditions and in that of the midshelf during storms) of a thin $(1-10 \mathrm{~cm}$ thick) oscillatory boundary layer. This is nested within the much thicker boundary layer of wind-driven or tidal currents. In such cases the bottom friction of the current is enhanced by the wave boundary layer, and the bottom friction associated with the waves is enhanced by the current. Over the past 15 years, boundary layer models appropriate to combined waves and currents over rough bottoms have been advanced by Smith [1977], Smith and McLean [1977], Grant and Madsen [1979, 1986], Davis et al. [1988], Christofferson and Jonsson [1985], and Glenn and Grant [1987]. Wave boundary layer models developed by Sleath [1987], Madsen [1991], and Trowbridge and Madsen $[1984 a, b]$ are also relevant to the general problem of shelf benthic dynamics. 
For wave-current boundary layers, most models consider three shear velocities: (1) $u_{*_{\mathrm{c}}}$ associated with the mean current shear stress above the wave boundary layer, (2) $u_{* w m}$ associated with the wave-induced bed stress; and (3) $u_{* \mathrm{cw}}$ associated with the combined wave-current shear stress within the wave-current boundary layer that has a thickness $\delta_{\mathrm{cw}}$ (approximately the same as the wave boundary layer). Laboratory experiments and field observations have demonstrated extensively that within the near-bottom region (lower than 1 or $2 \mathrm{~m}$ ) of fully turbulent boundary layers, where stress is nearly constant with elevation, the velocity varies linearly with the $\log$ of the elevation. This region is the so-called "log layer," within which a relatively simple relationship exists among elevationdependent velocity, shear velocity, and bed roughness as expressed by the widely used Prandtl-von Kármán equation. For the profile of the mean current velocities $u_{\mathrm{c}}$ in the $\log$ layer and within the wave-current boundary layer, Grant and Madsen [1979, 1986] give Prandtl-von Kármán expressions of the form

$$
u=\frac{u_{* \mathrm{c}}}{\kappa}\left(\frac{u_{* \mathrm{c}}}{u_{* \mathrm{cw}}}\right) \ln \frac{z}{z_{0}} \quad z \leq \delta_{\mathrm{cw}}
$$

or

$$
u_{\mathrm{c}}=\frac{u_{* \mathrm{c}}}{\kappa} \ln \frac{z}{z_{0 \mathrm{c}}^{\prime}} \quad z>\delta_{\mathrm{cw}}
$$

where $\kappa$ is von Kármán's constant $(\sim 0.41), z_{0}$ is the physical roughness of the bed $\left(z_{0}=k_{\mathrm{b}} / 30 ; k_{\mathrm{b}}\right.$ includes ripple roughness), and $z_{0 \mathrm{c}}^{\prime}$ is the apparent roughness felt by the current above $\delta_{\mathrm{cw}}$,

$$
z_{0 \mathrm{c}}^{\prime}=\delta_{\mathrm{cw}}\left(\frac{z_{0}}{\delta_{\mathrm{cw}}}\right)^{\gamma}
$$

in which

$$
\gamma=u_{* \mathrm{c}} / u_{* \mathrm{cw}} \text {. }
$$

An important feature of the Grant and Madsen [1986] model is its ability to account for variations in the angle between the current and the direction of wave travel. The various wave-current boundary layer models differ in the way in which the eddy viscosity $\varepsilon$ is treated. Most models consider $\varepsilon$ to be time invariant. An exception is the model of Trowbridge and Madsen $[1984 a, b]$ that utilizes a time-varying eddy viscosity to accommodate second-order effects (e.g., mass transport) associated with steep waves. The ways in which $\varepsilon$ is assumed to be distributed vertically differ considerably. By the formulations of Grant and Madsen [1979, 1986],

$$
\varepsilon=\kappa u_{* \mathrm{cw}} z \quad z<\delta_{\mathrm{cw}}
$$

or

$$
\varepsilon=\kappa u_{* \mathrm{c}} z \quad z>\delta_{\mathrm{cw}} .
$$

This has the unattractive characteristic of yielding a discontinuity in $\varepsilon$ at $\delta_{\mathrm{cw}}$. Similar discontinuities are also present in the model of Christofferson and Jonsson [1985]. Continuous eddy viscosity formulations are used by Wiberg and Smith [1983]. The model of Glenn and Grant [1987] extends the earlier models of Grant and Madsen [1979, 1986] to include the effects of stratification caused by sediment suspension; this model has recently become widely used [e.g., Vincent and Green, 1990; Cacchione and Drake, 1990; Drake and Cacchione, 1992; Drake et al., 1992].

\section{Field Observations of Bed Stress}

Field measurements of bed stress on the middle and outer shelf and on the continental slope have been made in recent years via the multi-institutional CODE and Sediment Transport Events on Shelves and Slopes (STRESS) research programs. Measurements during the earlier CODE programs on the northern California shelf utilized velocity profiles made with arrays of electromagnetic current meters (EMCMs) mounted on the Geological Processes Bottom Environmental (GEOPROBE) tripod as well as the benthic acoustic stress sensor (BASS) [Cacchione and Drake, 1990; Cacchione et al., 1984, 1987b; Grant et al., 1984]. The results showed $u_{\mathrm{c}}^{*}$ and $z_{0 \mathrm{c}}^{\prime}$ values of $0.5-1.0 \mathrm{~cm} \mathrm{~s}^{-1}$ and approximately $1 \mathrm{~cm}$, respectively. The higher than expected $z_{0 c}^{\prime}$ values were attributed to wave-current interactions [Grant et al., 1984; Drake et al., 1992]. Results of comparisons between GEOPROBE and BASS data show very good agreement for stormdriven flows [Cacchione and Drake, 1990]. More recently, BASS systems have been deployed at $130 \mathrm{~m}$ and $90 \mathrm{~m}$ at the STRESS site for a 2.5 -month experiment; analyses of these data sets are in progress [Williams, 1992; Williams et al., 1991].

Techniques for applying the inertial dissipation method to field data obtained from electromagnetic current meters in wave-current boundary layers on the shelf have been developed by Huntley [1988]. Green et al. [1992] show improved results from the dissipation method by applying a frequency-dependent gain correction to the current spectra. Huntley and Hazen [1988] applied the dissipation method to estimate bed shear stresses at $25 \mathrm{~m}$ and $45 \mathrm{~m}$ on the Nova Scotian shelf and showed that wave-current interactions significantly enhanced the mean current shear stresses in accordance with model predictions. Similar conclusions were reached by Green et al. [1990] for tidal currents in the North Sea (24-m depth) off the British coast. Electromagnetic current meters also were used to obtain velocity profiles on the inner shelf (7- to $13-\mathrm{m}$ depth) of the Middle Atlantic Bight under fair weather, swell-dominated, post-hurricane, and storm conditions [Wright et al., 1991b; Wright, 1993] and during a severe storm [Madsen et al., 1993]. The results showed that the highest $z_{0 c}^{\prime}$ values occurred during the swell-dominated conditions owing to the coexistence 
of a thick wave boundary layer and subtle ripples. Ripples were completely washed out during the storm, yielding a smoother bed with a movable plane bed roughness length $k_{n}$ of about 15 times the particle diameter [Madsen et al., 1993]. Similar observations were made for the U.S. west coast by Drake and Cacchione [1992].

\section{Bed Micromorphology}

In addition to determining $z_{0}$ and influencing $z_{0 \mathrm{c}}^{\prime}$, the small-scale relief (roughness) of the seafloor can profoundly affect the across-shelf direction of suspended sediment transport near the bed. For example, Nielsen [1979, 1981, 1989, 1992], among others, has demonstrated that wave-induced ripples can cause suspended sediment to migrate in a direction opposite to that of net near-bottom flows. Field observations over the inner shelf show that suspended sediment concentrations and bed stresses are out of phase when ripples are present [Wright et al., 1991a]. Hence modeling of across-shelf particle transport within and just above wave-current boundary layers requires prediction of the time-varying geometry for wave-generated ripples.

Existing models predict ripple height $\left(\eta_{\mathrm{r}}\right)$ and spacing $\left(\lambda_{r}\right)$ in terms of sediment grain size, the orbital semiexcursion of wave-induced flows at the bed, and the amount by which the skin friction shear stress (or Shields parameter) exceeds the critical value necessary for sediment entrainment. The models most widely used are those of Grant and Madsen [1982] and Nielsen [1981], both of which utilize laboratory data from the same sources. Nielsen [1981] also offers a separate set of predictors based on field data that generally give more realistic results. In most cases the Grant and Madsen [1982] model overpredicts the ripple roughnesses observed in the field. Although the model of Nielsen [1981] gives results closer to ripple dimensions observed in the field, Wright [1993] found that model to overpredict fair weather ripple heights and underpredict the dimensions during moderate- to high-energy conditions. This was attributed, in part at least, to the effects of grain size variability within the upper few centimeters of the sediment column [Wright, 1993].

Ongoing investigations, many of which are being carried out in connection with the STRESS program, are focusing on better predictions and parameterizations of bed micromorphology. Wiberg [1992], Harris and Wiberg [1991], and Wiberg and Nelson [1992] have improved wave-ripple predictability considerably. They show that much variability can be explained in terms of the Rouse number (ratio of settling velocity to shear velocity) and the wave boundary layer thickness. Nowell and Wheatcroft [1992] also conducted field studies of bed roughness including the combined effects of ripples, biogenic roughness, and scour-induced bottom irregularities. The importance of biogenic roughness generally increases seaward over the middle shelf. The interaction of benthos with hydrodynamic and sedimentary characteristics has been well demonstrated [Rhoads, 1974; Eckman et al., 1981; Grant et al., 1982; Nowell et al., 1989; Jumars, 1993].

\section{Sediment Resuspension and Transport}

Transport of particles within the bottom boundary layer takes place in two modes: suspended load and bed load. Krause and Horikawa [1990] consider sheet flow (highly energetic transport of a carpet of particles above a plane, unrippled bed) to constitute a third mode, although most investigators consider sheet flow to be a form of bed load transport. A fundamental difference between suspended load and bed load is this: in suspended load transport, particles are supported by turbulence, whereas in bed load transport the particles are supported at least intermittently by grain-to-grain contact (e.g., rolling or bouncing sand grains). Estimation of suspended load fluxes involves the integration over depth and time of the local, instantaneous product of across-shelf velocity $u$ and particle concentration $C$. Therefore after the nearbottom velocity profile is measured or modeled, the problem becomes one of measuring or modeling the vertical concentration profile $C(z)$.

By Rouse-type formulations, the time-averaged (i.e., over several wave cycles) elevation-dependent suspended sediment concentration $C(z)$ is predicted following Vincent and Green [1990] in terms of the reference concentration $C_{0}$ at elevation $z_{0}$ by

$$
C(z)=C_{0}\left(z / z_{0}\right)^{-\alpha} \quad z<\delta_{\mathrm{cw}}
$$

or

$$
C(z)=C_{\delta_{\mathrm{cw}}}\left(\mathrm{z} / \delta_{\mathrm{cw}}\right)^{-\alpha} \quad z>\delta_{c w}
$$

where the Rouse number $\alpha$ is

$$
\alpha=\beta w_{s} / \kappa u_{* \mathrm{cw}} \quad z<\delta_{c w}
$$

or

$$
\alpha=\beta w_{s} / \kappa u_{* \mathrm{c}} \quad z>\delta_{c w}
$$

where $w_{\mathrm{s}}$ is particle settling velocity, which in the simple case is assumed to be the same for all particles (single grain size), $\beta$ is a "constant" in the neighborhood of 1 , and $C_{\delta \mathrm{cw}}$ is concentration at the top of the wave boundary layer. Vincent and Green [1990] concluded, in agreement with Glenn and Grant [1987], that $\beta$ is $\sim 0.74$ in the region very close to the bed. However, Vincent and Green [1990] also found $\beta$ to increase to about 1 away from the bed. Smith and McLean [1977], Glenn and Grant [1987], and Kachel and Smith [1989] employed the relationship 


$$
C_{0}=C_{\mathrm{b}} \frac{\gamma_{0} \theta^{\prime}}{1+\gamma_{0} \theta^{\prime}}
$$

where $C_{\mathrm{b}}$ is sediment concentration in the bed and $\gamma_{0}$ is an empirically determined resuspension coefficient. The excess skin friction shear stress $\theta^{\prime}$ is obtained by averaging, over several wave cycles, the instantaneous value $\theta^{\prime}(t)$ given by

$$
\theta^{\prime}(t)=\frac{\left|\tau_{\mathrm{cw}}^{\prime}(t)\right|-\tau_{\mathrm{cr}}^{\prime}}{\tau_{\mathrm{cr}}^{\prime}}
$$

where $\tau_{\mathrm{cw}}^{\prime}$ is the instantaneous skin friction shear stress induced by combined wave and current flows and $\tau_{\mathrm{cr}}^{\prime}$ is the critical skin friction shear stress required for sediment movement.

Direct field measurements of $C(z, t)$ in recent years have been made using optical backscatterance (OBS) turbidity sensors [Downing et al., 1981; Sternberg et al., 1986; Wright et al., 1991a; Green et al., 1992], acoustic sensors [Vincent and Green, 1990; Hanes et al., 1988; Sherwood et al., 1991], and laser diffraction devices that also permit in situ determination of particle size and $w_{\mathrm{s}}$ [Lynch et al., 1991; Agrawal, 1991]. Field observations of $C(z)$ have been used to obtain estimates of the resuspension coefficient $\gamma_{0}$, which has been shown to vary from $1.6 \times 10^{-5}$ to $5.4 \times 10^{-3}$ [Wiberg and Smith, 1983; Kachel and Smith, 1989; Drake and Cacchione, 1989; Vincent and Green, 1990] although Smith and McLean [1977] assigned $\gamma_{0}$ a constant value of $2.4 \times 10^{-3}$. Utilizing data from the inner shelf off Duck, North Carolina, Kim [1990] concluded that the Smith and McLean [1977] value of $2.4 \times 10^{-3}$ was appropriate but also observed a tendency for $\gamma_{0}$ to decrease with increasing $\tau_{\mathrm{cw}}$. This latter tendency is consistent with the results of Drake and Cacchione [1989], who attributed the effect to bed armoring.

A major source of uncertainty in the modeling of sediment resuspension by flows that exceed the critical threshold shear stress $\tau_{c r}^{\prime}$ by only a small or moderate amount is the selection of appropriate values for $\tau_{\text {cr. }}^{\prime}$. Where sediments consist of mixtures of many sizes, include cohesive fines, or are modified by benthic biology, $\tau_{\text {cr }}^{\prime}$ may deviate appreciably from laboratory values. Techniques for obtaining in situ field measurements of $\tau_{\mathrm{cr}}^{\prime}$ using various types of seabed flumes have recently proven successful. A recirculating flume, Seaduct, was developed for use in the High Energy Benthic Boundary Layer Experiment (HEBBLE) [Nowell et al., 1985] following the earlier Seaflume concept of Young and Southard [1978]. Most recently, smaller and more readily deployable annular flumes have been developed and used effectively in shelf and coastal waters [Amos et al., 1992; Maa et al., 1991]. Applications of the Maa et al. [1991] flume demonstrate the importance of benthic biota in causing significant seasonal variability of $\tau_{\text {cr }}^{\prime}$ in some coastal environments [e.g., Wright et al., 1992].
Direct field measurement of bed load transport on the shelf is extremely difficult, and although promising new techniques are under development [e.g., Lowe et al., 1991] there is a lack of agreement as to whether or not this can be done with acceptable accuracy. Therefore bed load transport models are typically calibrated with laboratory data. A recent model developed by Wiberg and Smith [1989] utilizes the fundamental mechanics of individual saltating (hopping) sand grains to yield transport predictions without reliance on empirically determined constants. The model shows a good fit to data and offers insights into bed load transport by unidirectional flows. On the shelf, transport is most often the result of combined waves and currents. The bed load model of Madsen [1991] utilizes a generalized form of the Meyer-Peter and Muller bed load transport relationship and is appropriate to the situation of combined wave and current flows. Madsen's model considers the instantaneous bed load transport rate to be proportional to $\tau_{\mathrm{cw}}^{\prime}(t)\left(\tau_{\mathrm{w}}^{\prime}(t)\right)^{1 / 2}$. Models such as that of Madsen [1991] as well as the earlier energetics-type models [e.g., Bailard, 1981; Bailard and Inman, 1981] implicitly allow for orbital velocity asymmetries to be taken into account. However, Conley and Inman [1992] recently obtained an impressive set of photographic time series of bed layer behavior under nearbreaking waves that shows an additional source of transport asymmetry that is not observable in the laboratory. They found that roiling and pluming develop in the sediment-laden bed layer under the wave crest but not under the wave trough. They attribute this effect to ventilation of the permeable bed by the pressure differentials associated with the shoaling, shallow-water waves. This process is probably operative only in the region just outside the surf zone.

Over the middle regions of many continental shelves, sediments are muddy and cohesive. Off the mouths of large rivers, larger portions of the shelf can be covered with muddy sediments (e.g., the Amazon shelf [Nittrouer et al., 1986]). Cohesive sediments respond differently than sands in that the $\tau_{c r}^{\prime}$ is often higher and deposition occurs at much lower levels of skin friction shear stress. The problems of cohesive sediment transport have been the subject of several recent reviews [Nichols and Biggs, 1985; Mehta, 1986; Uncles, 1987; Mehta and Hayter, 1989].

\section{GEOLOGICAL MANIFESTATIONS OF ACROSS-SHELF TRANSPORT}

Over time scales longer than the typical observation periods of instrumented systems (i.e., greater than about a month), evidence for across-shelf transport of particulate material can be recognized in characteristics of sedimentary deposits (e.g., shelf morphology, sediment composition, and accumulation rates). These characteristics can be used to investigate net patterns 
of transport and the time-integrated effects of processes as well as to compare with short-term predictions and observations.

\section{Bed Load Transport}

Observations of sediment convergence and divergence (parting) have been made for sandy areas dominated by bed load transport, usually driven by tidal currents. Kenyon and Stride [1970] clearly demonstrated transport through the seas surrounding the British Isles. Estuary-shelf exchanges between Bristol Channel and the Celtic Sea also have been recognized [Stride, 1963], although subsequent studies have been contradictory [Harris and Collins, 1985, 1988, 1991; Stride and Belderson, 1990, 1991]. The fundamental question associated with these tidal currents is whether net transport or nearly balanced reversing flow occurs. In this area, grain size reveals a progressive decrease westward into the Celtic Sea and suggests seaward transport. A budget for the system indicates a total of $64 \times 10^{5} \mathrm{t} \mathrm{yr}^{-1}$ of sediment in movement but fails to recognize the net seaward flux [Harris and Collins, 1988].

Sand movement associated with shelf sand ridges generally reveals across-shelf transport (depending on the orientation of the tidal ellipse), but particulate flux is a circulating transport around the ridge [e.g., Smith, 1969; Malikides et al., 1989]. Net transport can be inferred from asymmetries in ridge morphology, but fields of tidal sand ridges demonstrate significant spatial variability in the direction of net transport (e.g., in Torres Strait between Australia and New Guinea [Harris, 1988]). Net transport is possible during storms, when currents interact with the ridge morphology. This mechanism has been suggested to transport sand particles $100 \mathrm{~km}$ seaward over the Norfolk Banks, in the North Sea (Figure 8 [Stride, 1988]. The superposition of storm and tidal flows (without the need for morphologic effects) has been recognized as an important across-shelf transport mechanism for the sandy shelves of eastern Canada [Amos and Judge, 1991].

Across-shelf sediment transport in the shore face (concave upward region, seaward of the beach) similarly suggests bidirectional fluxes and little or no net transport. The flux associated with oscillatory wave flow is landward. However, the mean current flux (undertow) is offshore [Osborne and Greenwood, $1992 a$ ], and the net effect is presumed to be a balance with little net flux. This situation becomes more complex for barred coastal areas, where transport is spatially dependent on the location relative to the bar [Osborne and Greenwood, 1992b]. Temporal variability also is observed where storm and nonstorm transport are contrasted. Over the shore face of Long Island, landward transport was inferred during fair weather conditions; seaward transport prevailed dur-

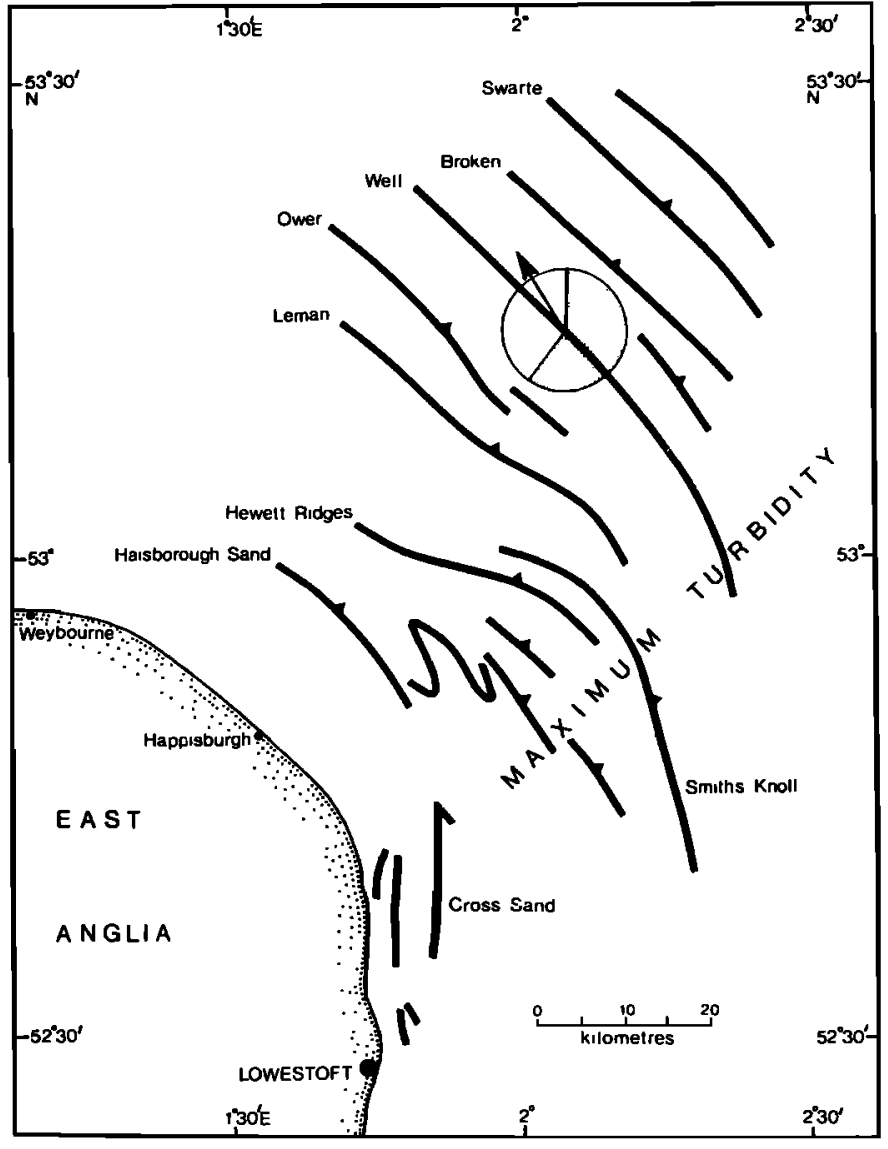

Figure 8. Norfolk sand banks on the east coast of the United Kingdom. The solid lines show the axes of banks, and the ticks indicate the steeper side (direction of migration). The direction of tidal currents is shown by the arrow and is only slightly oblique to the ridges. During storms, sediment is swept seaward from one bank to another. Fine-grained sediment typically is transported along the path indicated as maximum turbidity. From Stride [1988].

ing a "northeaster" storm [Niedoroda and Swift, 1981; Niedoroda et al., 1984].

Sandy sediment transported landward by surface wave activity is recognized on numerous beaches, where material is observed with the only potential source found seaward, for example, oolites in northeastern Florida and phosphorites in North Carolina (Figure 9 [Pilkey and Field, 1972]) or quartz sand in southwestern Florida [Parkinson, 1991]. This sort of landward transport probably reflects fair weather conditions, whereas evidence of seaward transport is observed in association with storms. The passage of hurricane Carla across the Texas coast resulted in the seaward transport of beach and nearshore sediment to form a graded sand layer $\sim 4 \mathrm{~cm}$ thick (Figure 10 [Morton, 1981; Snedden et al., 1988; Snedden and Nummedal, 1991]). Nelson [1982] observed similar storm layers on the Bering Sea shelf, where the thicknesses of some layers reached $10-20 \mathrm{~cm}$. Bedforms found on the inner continental shelf of northern California suggest seaward transport, and Cacchione et al. 


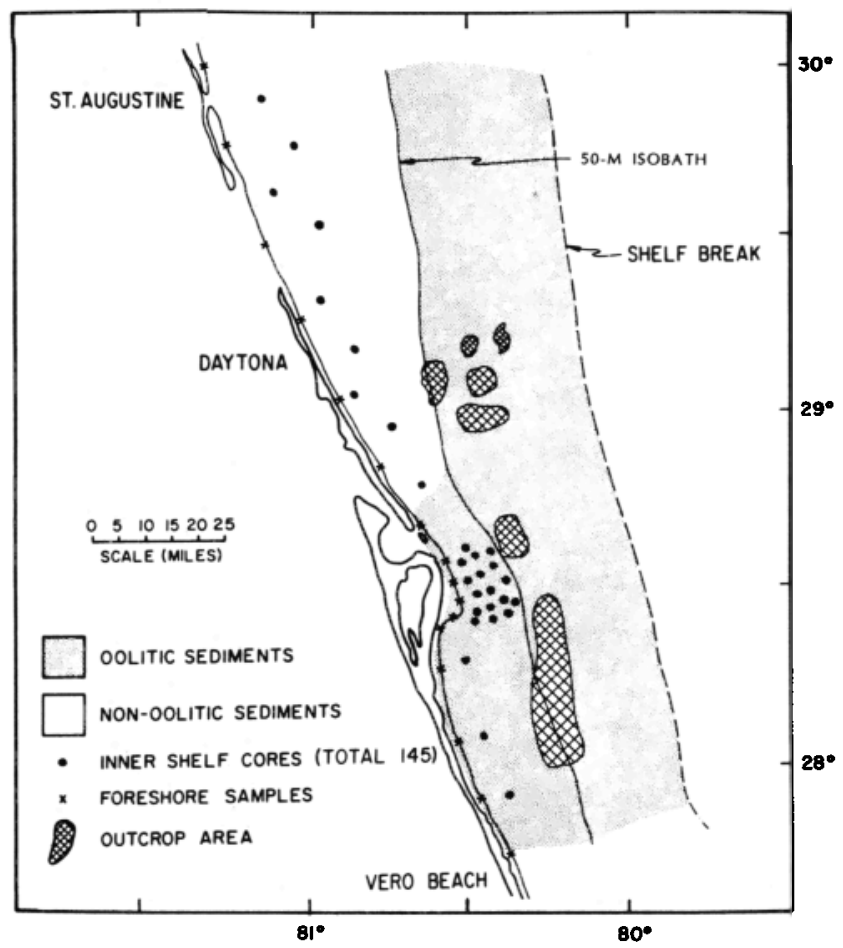

Figure 9. Distribution of oolitic sediment and its sources along the eastern Florida shelf. Rock outcrops are the source and are found at several locations in the midshelf region. Oolitic sediment eroded from the source areas is found on the surrounding shelf and is also found in the foreshore beach locations along the coast. From Pilkey and Field [1972, reprinted by permission].
[1984, 1987a] and Cacchione and Drake [1990] conclude that the transport is driven by storm-generated coastal downwelling. Field and Roy [1984] suggest that downwelling storm flows are responsible for transporting sands to the inner shelf along southeastern Australia and that long-term operation of this process has created thick $(10-30 \mathrm{~m})$ sand bodies. In contrast to these other observations, storm deposits (from cyclone Winifred) on the northeastern Australian shelf indicate erosion and landward transport of fine-grained sediment from the midshelf to the inner shelf [Gagan et al., 1990].

\section{Suspended Load Transport}

Observational studies that have measured suspended sediment transport rates on continental shelves routinely document strong along-shelf and weak across-shelf flows. Sediment emanating from the Ebro River of Spain is transported alongshelf (southward) under both fair weather and storm conditions with a slight offshore component [Cacchione et al., 1990]. On the U.S. shelf near New Jersey, Butman et al. [1979] document sediment resuspension primarily during storms, with particle excursions of $20-30 \mathrm{~km}$ along shelf (southwestward) and 5-10 km across shelf. Similar observations were made by Lyne et al. [1990b] for a study area farther northeast (off Cape Cod). Drake and Cacchione [1985] demonstrate for the
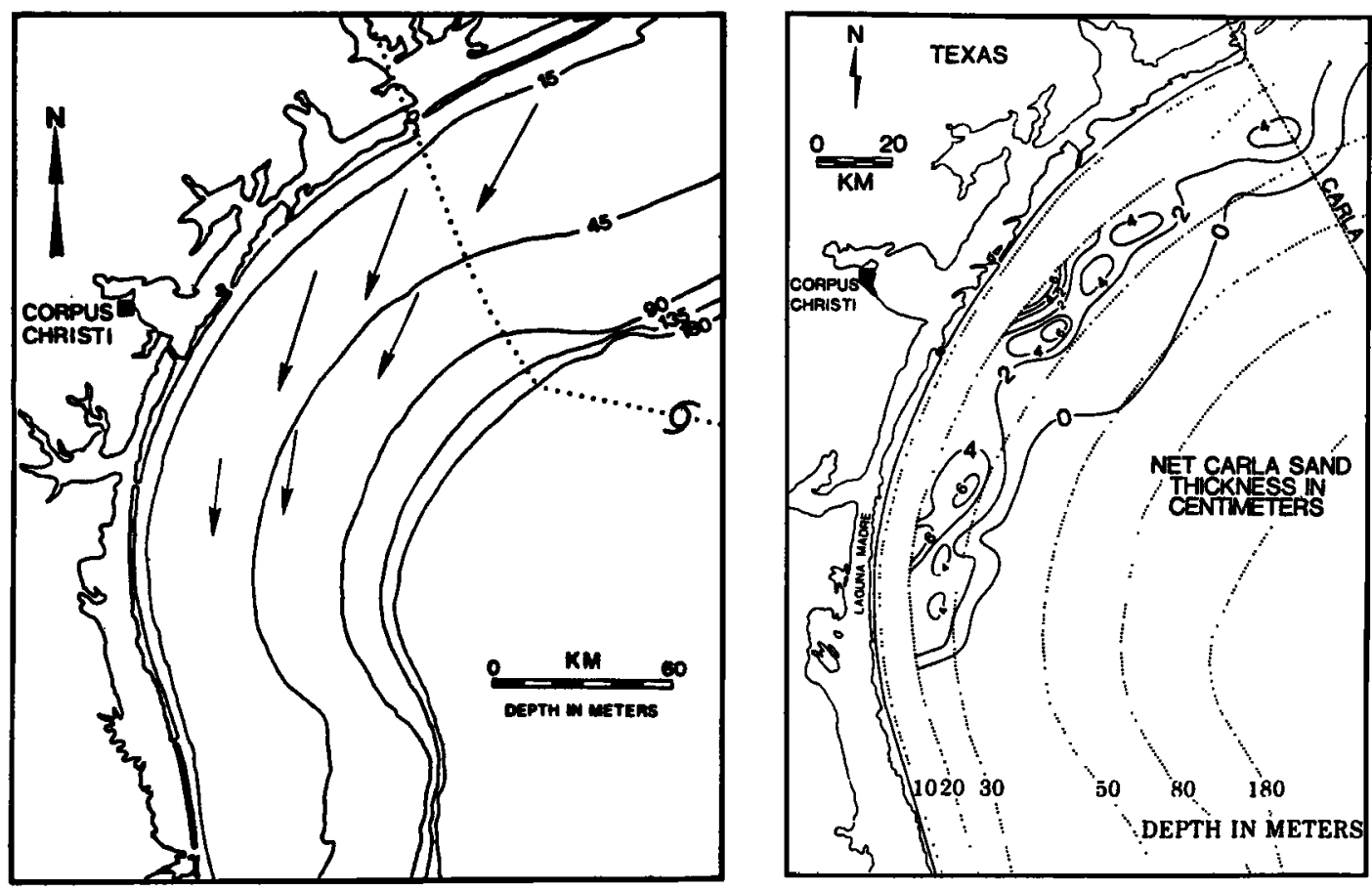

Figure 10. The seaward transport of sand by hurricane Carla (in 1961) to form a sand bed on the continental shelf of Texas. The left figure shows the path of the hurricane (dotted line) and the near-bottom currents that resulted (arrows). These currents coupled with the effects of surface gravity waves produced a distinct sand deposit on the inner and middle shelf, as shown in the right figure. From Snedden and Nummedal [1991]. 


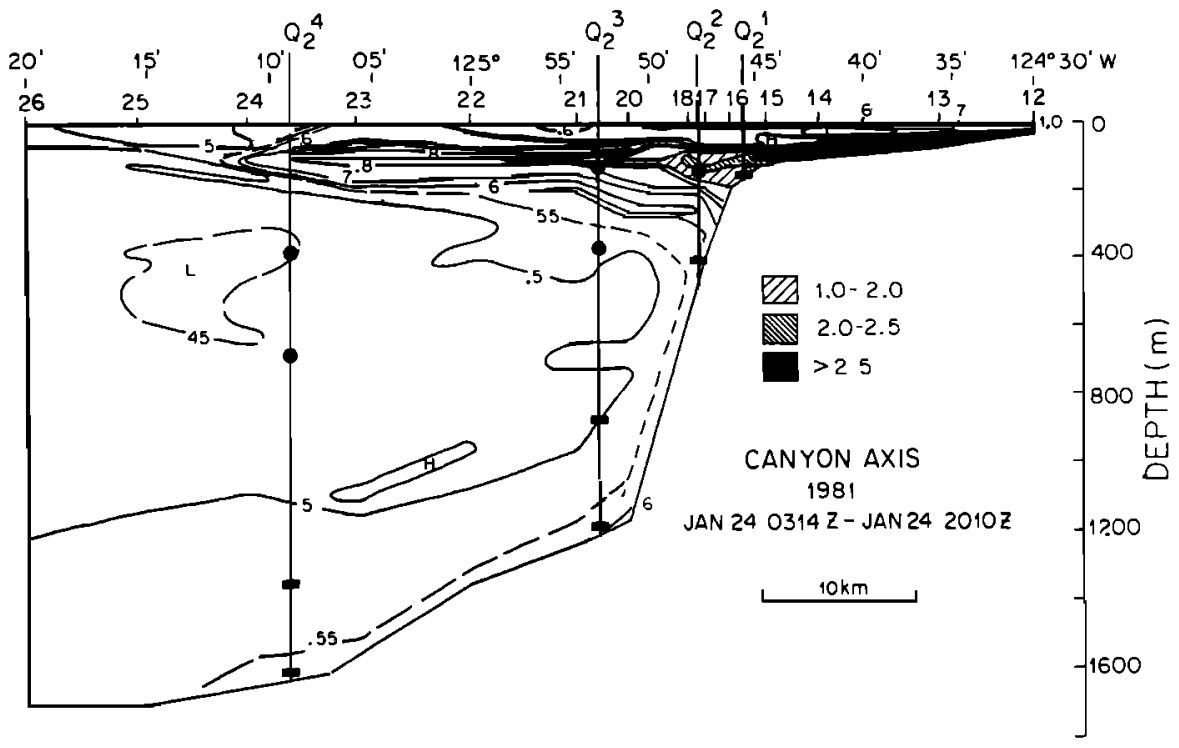

Figure 11. An intermediate-depth nepheloid (turbid) layer is produced during storms on the Washington continental shelf. The layer (and its particulate content) is advected northward along shelf, but also across shelf. This figure shows isopachs of light attenuation (in reciprocal meters) at the location of Quinault submarine canyon (see Figures 13 and 14). Longitude and station numbers are given across the top; vertical lines represent mooring locations. From Baker and Hickey [1986]. northern California shelf that most particulate transport is northward along shelf during storms, but with a significant offshore component (up to $45^{\circ}$ ).

A more subtle pattern of across-shelf transport occurs in association with seaward displacement of the shelf-slope front. This feature is well developed on the U.S. east coast and demonstrates a high-turbidity layer at its base. Turbid water is advected seaward when physical conditions cause frontal motion in that direction [Churchill et al., 1988; Palanques and Biscaye, 1992].

High concentrations of suspended particles are found as discrete layers near the seabed and at intermediate water depths. On the Texas shelf the turbid layers (nepheloid layers) are formed nearshore by fluvial discharge and are transported along shelf and seaward by ambient currents [Sahl et al., 1987; Halper and McGrail, 1988]. This seaward advection supplies sediment for accumulation on the midshelf region, and also leads to formation of intermediate-depth nepheloid layers as the bottom nepheloid layer becomes detached from the seabed. Seaward transport is intensified during storms on the Texas shelf [McGrail and Carnes, 1983]. Formation of intermediate nepheloid layers is particularly well developed on the Washington shelf during storms (Figure 11), when surface wave and current stresses resuspend sediment that is then advected along shelf as a bottom nepheloid layer [Hickey et al., 1986]. This layer becomes an intermediate-depth nepheloid layer where it passes over the heads of submarine canyons (indenting the shelf) or where it diffuses seaward toward the continental slope [Baker and Hickey, 1986]. Particles settling from the nepheloid layer complete the process of seaward transport.

Surface wave resuspension is generally observed to be an important process for seabed erosion, with subsequent advection dependent on local currents. In addition to the storm processes described above, swell conditions also can lead to seaward transport. On the San Pedro shelf (off southern California) low-amplitude (height $<1 \mathrm{~m}$ ), long-period ( $>10 \mathrm{~s}$ ) swell resuspends sediment, which is carried seaward by a weak mean flow [Drake et al., 1985]. In deeper areas of the shelf (middle and outer), where resuspension by surface waves is less effective, the results of human fishing activities can significantly impact seaward sediment transport. Churchill [1989] concluded that trawling activities in the U.S. Middle Atlantic Bight resuspend significant amounts of bottom sediment that are subsequently advected seaward by across-shelf water motions.

\section{Dispersal of Fluvial Sediments}

Rivers that empty onto epicontinental shelves or quiescent seas (e.g., the Gulf of Mexico or Mediterranean Sea) typically have less energetic dispersal systems, allowing particulate material to accumulate near the river mouth. In many cases, this causes deltaic progradation with subsequent sediment accumulating on the shelf farther seaward (e.g., Mississippi [Coleman, 1976], Po [Boldrin et al., 1988; Frignani and Langone, 1991], Ebro [Palanques and Drake, 1990], and Adige river [Boldrin et al., 1992]). Fluvial sediment discharge can be displaced much farther seaward (to hundreds of kilometers) in more energetic shelves, forming subaqueous deltaic features that prograde seaward (e.g., the Amazon [Nittrouer et al., 1986], Ganges-Brahmaputra [Kuehl et al., 1989], and Fly rivers [Harris et al., 1993]).

Within an epicontinental shelf setting, across-shelf particle dispersal is difficult to define; however, following dispersal systems toward deeper water is one approach. Within the Yellow Sea, studies of grain size (Figure 12 [Niino and Emery, 1961; Lee and Chough, 1989]) and mineralogy [Chough and Kim, 1981; Milli- 

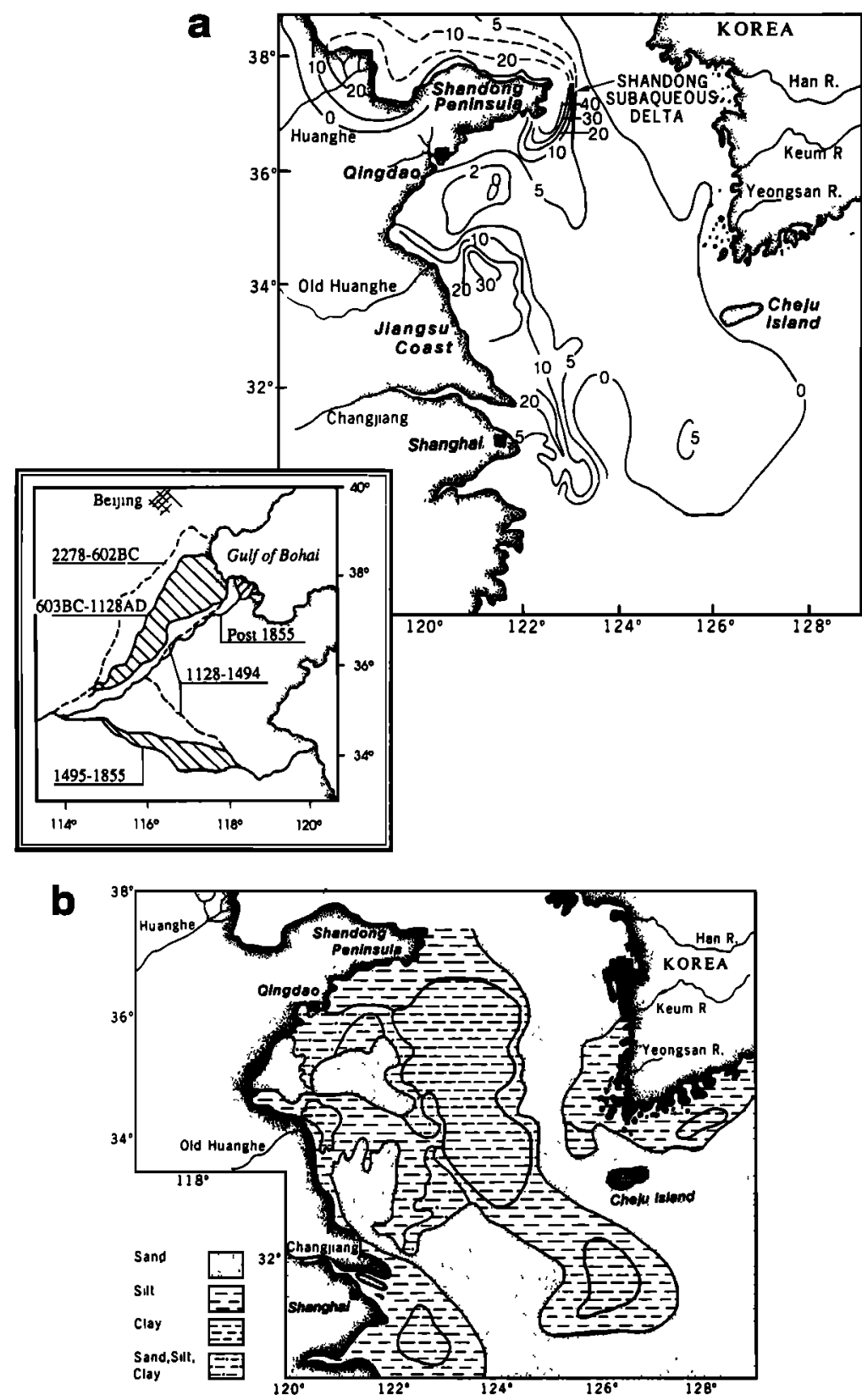

Figure 12. The distribution of Holocene sediment thickness and grain size in the Yellow Sea epicontinental shelf. The primary sediment source is the Huanghe (Yellow River), which has emptied into the Gulf of Bohai for most of the Holocene (Figure 12a, inset). A tongue of Huanghe sediment is observed to extend seaward along the axis of the Yellow Sea. Sediment thickness (Figure 12a) generally thins in that direction, and grain size (Figure 12b) and mineralogy reflect this dispersal pathway. From $\mathrm{Al}$ exander et al. [1991]; based partially on data from Milliman et al. [1987]. man et al., 1985; Park et al., 1986; Park and Khim, 1992] clearly demonstrate the displacement of sediment from the Huanghe and from Korean rivers southward toward the deeper Pacific Ocean. Within pericontinental shelf settings, across-shelf transport from source to sink is more simply delineated. For example, Pujos and Javelaud [1991] can trace the seaward dispersal of modern sediment from Colombian rivers by specific mineralogic assemblages (rich in chlorite and illite), and Segall and Kuehl [1992] can follow chloriterich sediments from the Himalayas across the Bangladesh shelf and into a submarine canyon.

The mineralogy and organic composition of suspended sediment on the U.S. east coast indicate the presence of particles from adjacent rivers to be significant only in nearshore waters $(<35 \mathrm{~m})$ [Meade et al.,
1975]. However, in other areas the composition of suspended and bottom sediments clearly indicates land-derived material reaching the middle and outer shelf and even the continental slope. Along the Washington coast, the Columbia River supplies a unique montmorillonite signal, which can be recognized in sediments of the adjacent water column and modern shelf-slope deposits [Knebel et al., 1968; Baker, 1973, 1976; Karlin, 1980]. The coniferous vegetation of the Columbia drainage basin similarly puts a fingerprint on the organic fraction of modern shelf-slope deposits [Hedges and Mann, 1979; Prahl, 1985]. A unique tracer of Columbia River sediment is ash delivered by the Mount Saint Helens eruption in 1980. Ridge and Carson [1987] traced the ash through the Columbia River dispersal system and, within 17 
months of its release to the ocean, observed it at least $125 \mathrm{~km}$ along shelf and $40 \mathrm{~km}$ across shelf from the river mouth (Figure 13). The seaward component of flow is explained by turning of the current, due to frictional interaction with the seabed [Kachel and Smith, 1986].

In the case of the Ebro River the sediment is muddy and its character is sufficiently cohesive to inhibit erosion and rapid dispersal. Ultimately, storms carry the sediment southward [Cacchione et al., 1990]. Some accumulates on the shelf as a midshelf mud deposit [Maldonado et al., 1983; Nittrouer et al., 1988], and other sediment is transported off the shelf near the Columbretes Islands [Palanques and Drake, 1990].

Anthropogenic input of various materials provides good tracers for across-shelf transport of particles. Particle-reactive chemical species are especially good tracers because they are adsorbed to the surface of the particles. The seaward dispersal of trace and heavy metals has been documented in many areas (e.g., the western Mediterranean [Palanques et al., 1990] and Adriatic Sea [Boldrin et al., 1988]). Man-made radioisotopes provide an identifiable tracer as well as an internal clock. The nuclear reactor in Hanford, Washington, supplied the Columbia River with an interesting assortment of isotopes. These were used to trace the oceanic dispersal of Columbia River sediment and to estimate its rate of transport [Gross and Nelson, 1966; Cutshall et al., 1986].

\section{Sediment Budgets}

Perhaps the best quantitative support for acrossshelf transport comes from fluvial sediment budgets. These budgets contrast the mass of a particulate source with the oceanic sinks and are produced from spatial distributions of accumulation rates. Rates are calculated with a range of tools (e.g., radioisotopes, varves, and sediment traps) and represent time scales of months to millennia. Across-shelf transport is demonstrated where significant amounts of sediment are accumulating on the continental shelf or slope, and compositional studies (e.g., mineralogy or organic content) require a source landward or seaward.

The southern California continental borderland contains numerous basins, which have accumulated a combined total of $14 \times 10^{10} \mathrm{t}$ of sediment [Schwalbach and Gorsline, 1985]. Most of this material $(>80 \%)$ is from fluvial sources on land. The sediment accumulates in the basins, which represent about $20 \%$ of the areal extent for the borderland, and ${ }^{210} \mathrm{~Pb}$ accumulation rates reach $1 \mathrm{~mm} \mathrm{yr}^{-1}$ (about $100 \mathrm{mg} \mathrm{cm}^{-2} \mathrm{yr}^{-1}$ ) [Bruland et al., 1981; Malouta et al., 1981]. Particulate deposition rates observed from sediment traps are consistent with the ${ }^{210} \mathrm{~Pb}$ rates and indicate a distinct seaward decrease, supporting lateral transport from shore [Huh et al., 1990].

Most continental shelves have a smoother surface than the shelf off southern California, and fluvial sediment typically forms continuous tongues of accumulation emanating from river mouths. The Columbia River discharges approximately $10^{7} \mathrm{t} \mathrm{yr}^{-1}$ of sediment, and approximately two thirds accumulates on the Washington shelf north of the river mouth [Nittrouer, 1978; Nittrouer et al., 1979]. The particle size and mineralogy clearly identify a Columbia River source for the sediment. The axis of highest accumulation rates is found on the midshelf (water depth of 50-150 $\mathrm{m}$ ), as a tongue extending predominantly along shelf but also crossing isobaths seaward (Figure 14). Accumulation rates along the axis decrease from about 7 to $3 \mathrm{~mm} \mathrm{yr}^{-1}\left(1.0-0.4 \mathrm{~g} \mathrm{~cm}^{-2} \mathrm{yr}^{-1}\right)$ with distance from the river mouth and also decrease landward and seaward. Some of the Columbia River sediment escapes to the continental slope, but accumulation rates are significantly lower there than on the shelf [Carpenter et al., 1982; Thorbjarnarson et al., 1986].

Budgets also have been developed for larger fluvial systems. The Fly River (Papua New Guinea) discharges nearly $10^{8} \mathrm{t} \mathrm{yr}^{-1}$ of sediment. About half of this accumulates as a seaward prograding deposit near the river mouth, and the other half is transported into the Gulf of Papua with a significant across-isobath component (Figure 15 [Harris et al., 1993]). The Changiiang (Yangtze River, China) discharges more than $10^{8} \mathrm{t} \mathrm{yr}^{-1}$ of sediment. Approximately $40 \%$ accumulates as a seaward prograding deposit near the river mouth, and much of the remainder is transported southward, forming a sedimentary deposit that extends to about the $60-\mathrm{m}$ isobath [DeMaster et al., 1985]. An important observation near the mouth of the Changiang is the significance of timescale. The budgets for areas described above were obtained from ${ }^{210} \mathrm{~Pb}$ geochronology (half-life, 22.3 years) in sediment cores, which therefore integrate accumulation rates over decades. McKee et al. [1984] observed that the ${ }^{210} \mathrm{~Pb}$ accumulation rates near the mouth of the Changiiang (about $5 \mathrm{~cm} \mathrm{yr}^{-1}$ ) were significantly slower than short-term (integrated over several months) summer deposition rates (about $5 \mathrm{~cm} \mathrm{month}^{-1}$ ) from ${ }^{234} \mathrm{Th}$ analyses (half-life, 24 days). The difference represents erosion of sediment during winter storms and its transport across and along shelf away from the river mouth.

Budgets for the Huanghe (China) and Amazon fluvial systems each examine the fate of more than $10^{9} t$ $\mathrm{yr}^{-1}$ of sediment. Approximately 85-90\% of the Huanghe discharge accumulates near the river mouth in the Gulf of Bohai [Bornhold et al., 1986; Alexander et al., 1991]. The remaining 10-15\% (representing $>10^{8} \mathrm{t}$ $\mathrm{yr}^{-1}$ ) extends southward down the axis of the Yellow Sea as a tongue toward deeper water. In contrast to the epicontinental shelf setting for the Huanghe discharge, the Amazon enters a pericontinental shelf. More than half of the sediment accumulates on the adjacent shelf, with the highest rates $\left(>10 \mathrm{~cm} \mathrm{yr}^{-1} ;>7\right.$ $\mathrm{g} \mathrm{cm}^{-2} \mathrm{yr}^{-1}$ ) found in the midshelf (40- to $60-\mathrm{m}$ water 


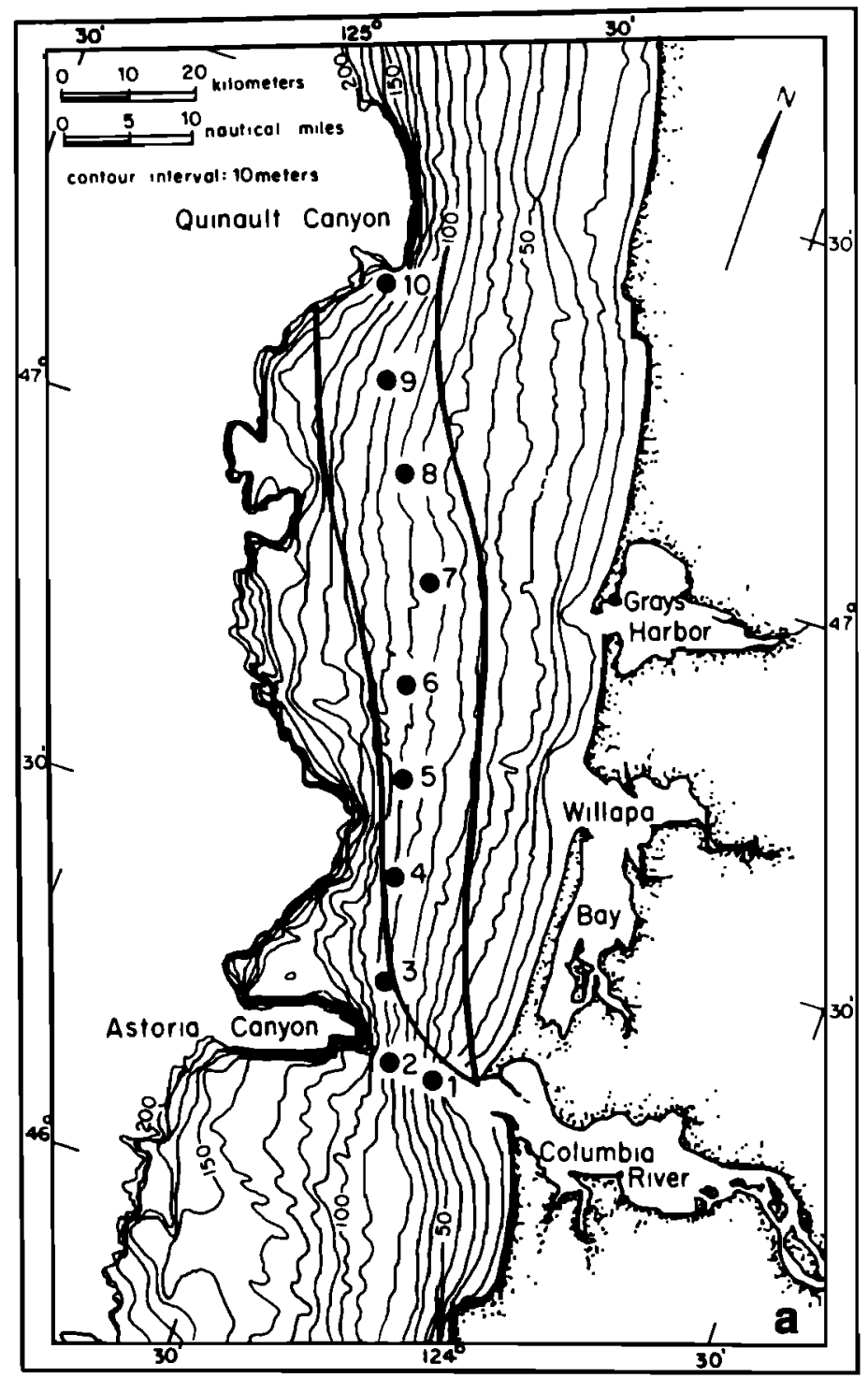

Figure 13. Observations of volcanic ash originating from Mount Saint Helens (eruption of May 1980) and discharged to the Washington shelf by the Columbia River. Ten stations were sampled along the path of sediment transport (Figure 13a), and the arrival times at each are shown in Figure 13b. Seventeen months after the eruption, volcanic ash had traveled at least $125 \mathrm{~km}$ along shelf and $40 \mathrm{~km}$ across shelf. From Ridge and Carson [1987].

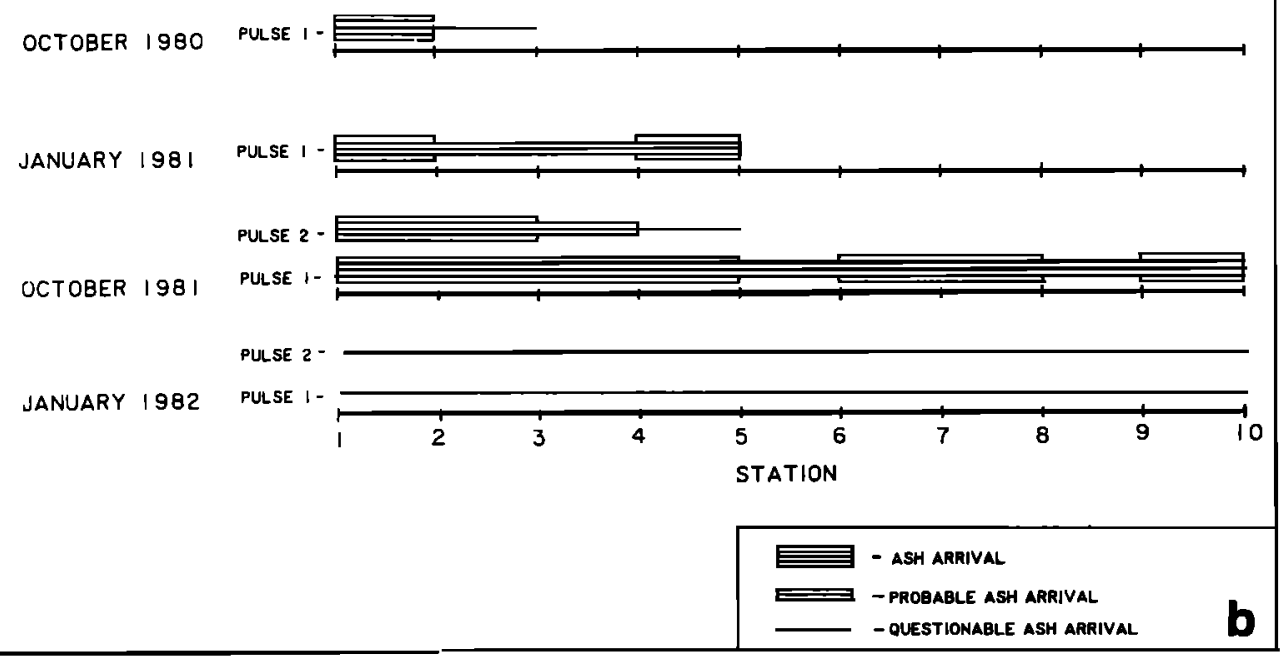




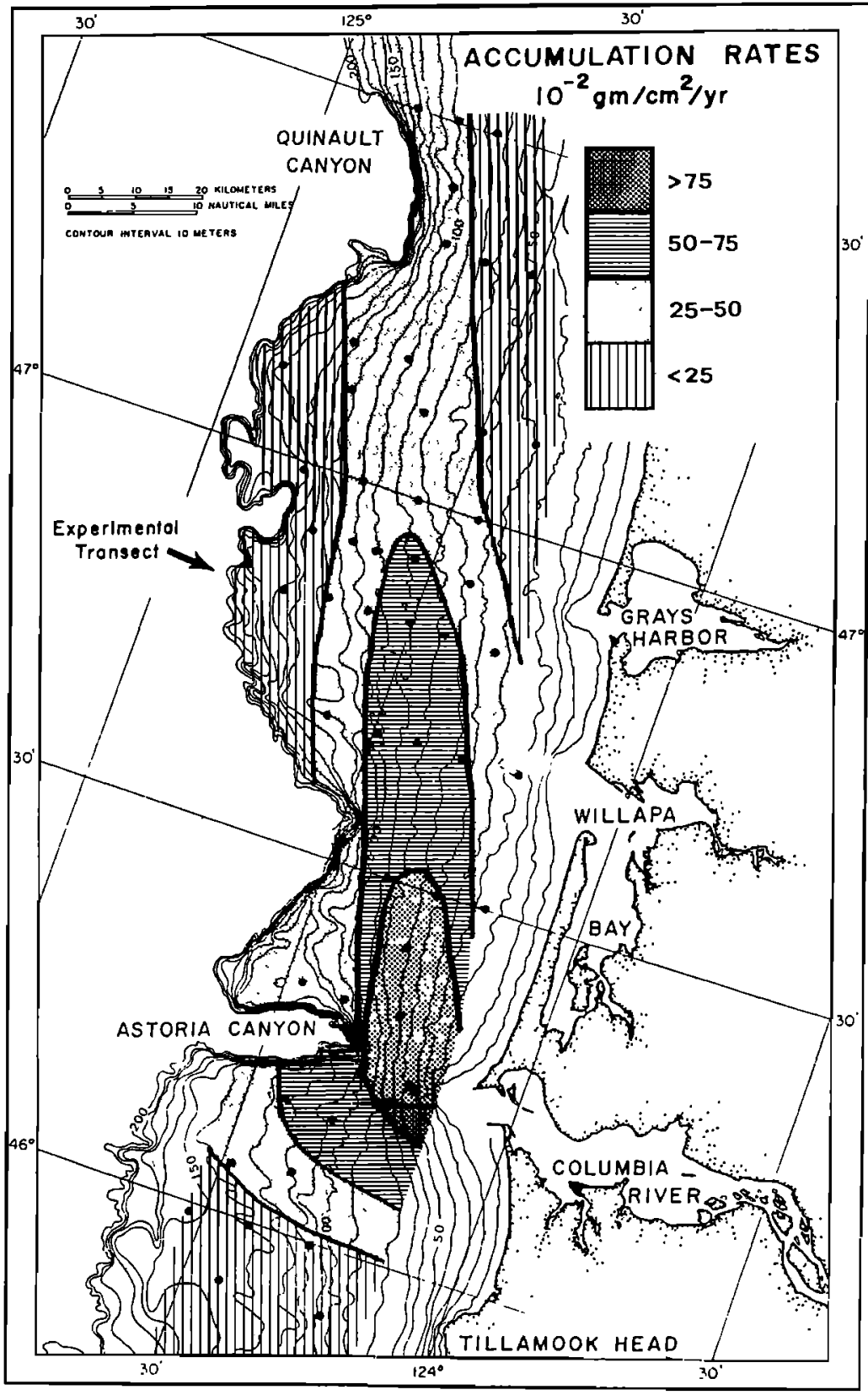

Figure 14. Sediment accumulation rates determined by ${ }^{210} \mathrm{~Pb}$ geochronology for the Washington continental shelf. The axis of highest accumulation rates is found on the middle shelf as a tongue extending predominantly along shelf but also crossing isobaths. From Nittrouer [1978]. depth; Figure 16) region [Kuehl et al., 1986]. Much of the remainder is transported northwestward farther along the shelf.

The midshelf region is recognized worldwide as a location where modern sediment accumulates, usually muddy sediment [McCave, 1972; Nittrouer and Sternberg, 1981]. In some cases, such as the Washington continental shelf, the transition from inner shelf to midshelf occurs in the presence of moderate sediment supply, where accumulation rates are millimeters per year. In other cases, such as the Amazon shelf, the transition occurs in a realm of much greater sediment supply, and accumulation rates are centimeters per year. The transition from the inner shelf to midshelf can be from sand to mud or from mud to mud. Accumulation rates can increase abruptly or gradually. The transition can occur on narrow, steep margins or broad, gently sloping margins. But as a general rule, across-shelf transects of sediment accumulation rate reveal values that increase significantly just seaward of the inner shelf-midshelf boundary and reach greatest values on the midshelf (Figures 14 and 16). Because much of the sediment accumulating there has a terrestrial origin, across-shelf transport is demonstrated by the presence of a midshelf deposit. However, because much material accumulates there, the midshelf region is also the dead end for many of the particles transported across continental shelves. 


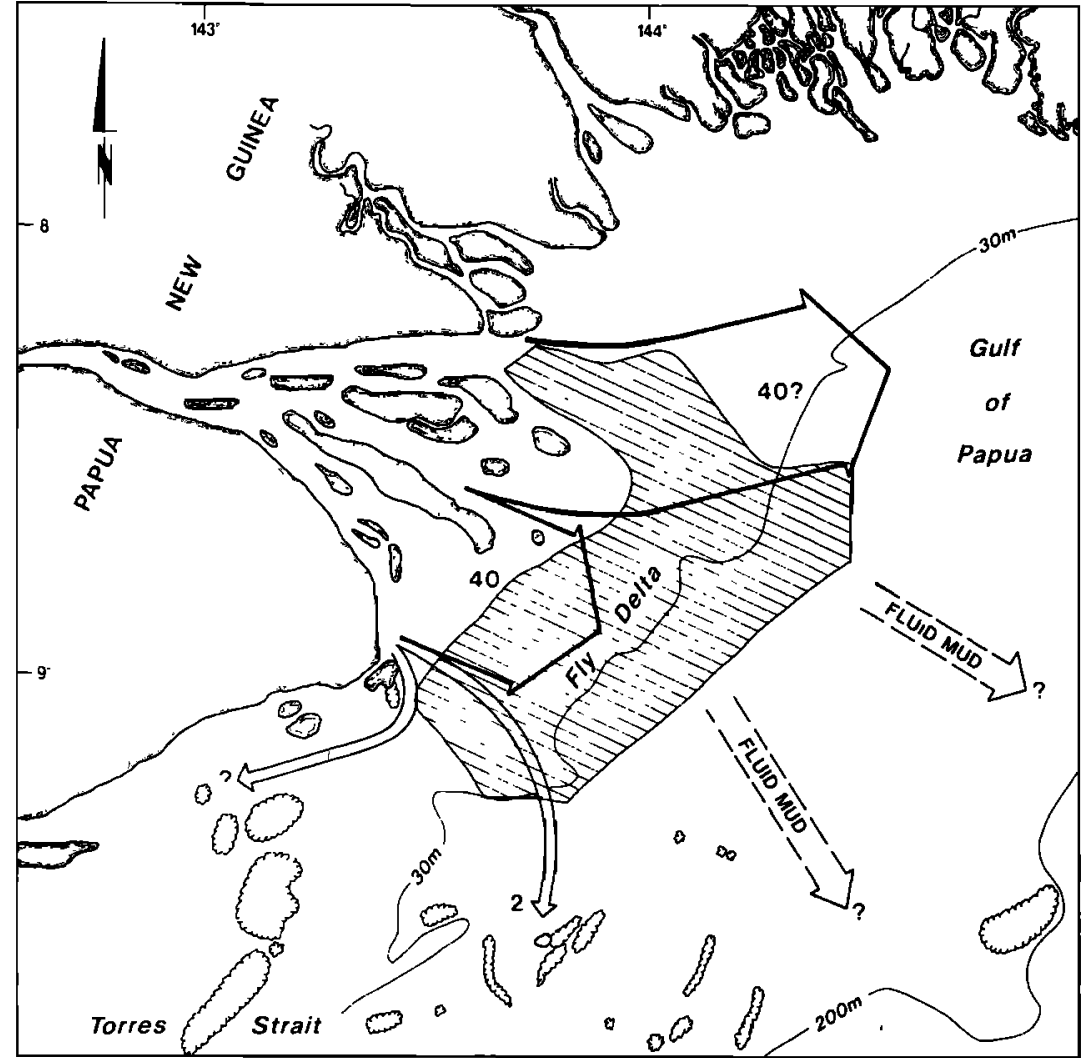

Figure 15. Schematic budget for sediment discharged by the Fly River, Papua New Guinea. Approximately half of the discharge (equal to about $40 \times 10^{6} \mathrm{yr}^{-1}$ ) is accumulated as part of a seaward prograding subaqueous delta. Most of the remaining sediment is transported seaward into the Gulf of Papua. From Harris et al. [1993].

\section{PROJECTIONS FOR FUTURE RESEARCH}

Across-shelf transport controls the fate of diverse and important particles. Many organisms develop through planktonic larval stages, whose successful dispersal depends on across-shelf transport. Many particle-reactive chemical species (natural and man-made) have terrestrial sources, and their fates depend on across-shelf transport. Even global $\mathrm{CO}_{2}$ budgets are affected by the transport of particulate carbon synthesized in highly productive shelf waters. As concern for coastal waters increases, continued attention should be given to the topic of particulate transport across continental shelves. Both basic and applied research studies are needed. Work to date, as outlined in this review, represents a preliminary contribution toward a comprehensive understanding of across-shelf transport. No coordinated effort has been undertaken to address the range of driving processes nor their results over a diversity of timescales.

Future work should continue to evaluate the operation of oceanic processes and their tie to particle transport. Many of the most successful projects have attempted to isolate one or two dominant processes (e.g., wind-driven flows or buoyant plumes). This approach should continue so that fundamental knowledge of each process can further develop. How- ever, the ocean is a complex milieu, and many shelves are strongly influenced by two or more processes. Where several processes influence particle transport, their coupling can be distinctly nonlinear (e.g., effects from combined surface gravity waves and steady currents). Future studies also should address complex study areas with a variety of energetic processes, including diverse biological and geological characteristics.

A strong message from this review is that acrossshelf particulate transport is bidirectional. Most of the driving processes are capable of reversing direction, and field observations verify the reversals. Although the present theoretical base is able to predict particle transport rates, the associated confidence limits commonly prevent identification of net transport when two large transport rates are contrasted for systems with reversing flows. Empirical observations seldom cover a period sufficient to resolve this problem. Theoretical and technological advances should be encouraged in order to improve this situation. However, longer sampling periods (i.e., monitoring of shelf environments) also should be encouraged. This will improve knowledge of bidirectional particulate transport and also will provide valuable insight regarding the integrated effects of processes spanning different time scales. 


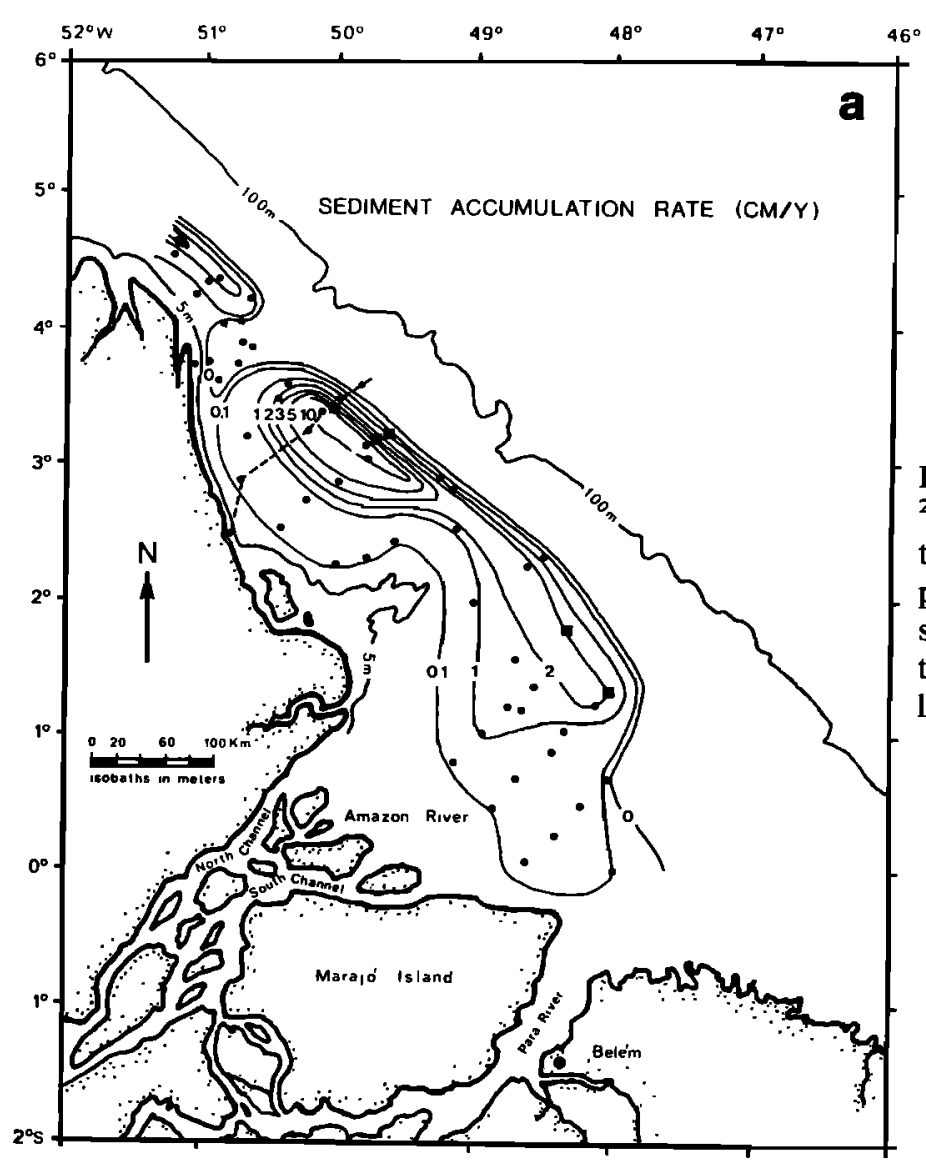

Figure 16. Sediment accumulation rates determined by ${ }^{210} \mathrm{~Pb}$ geochronology for the continental shelf adjacent to the Amazon River. Maximum accumulation rates are present in the midshelf region, where the leading edge of a subaqueous delta is prograding seaward. Figure $16 b$ shows the morphology and accumulation rates across the dashed line of Figure 16a. From Kuehl et al. [1986].

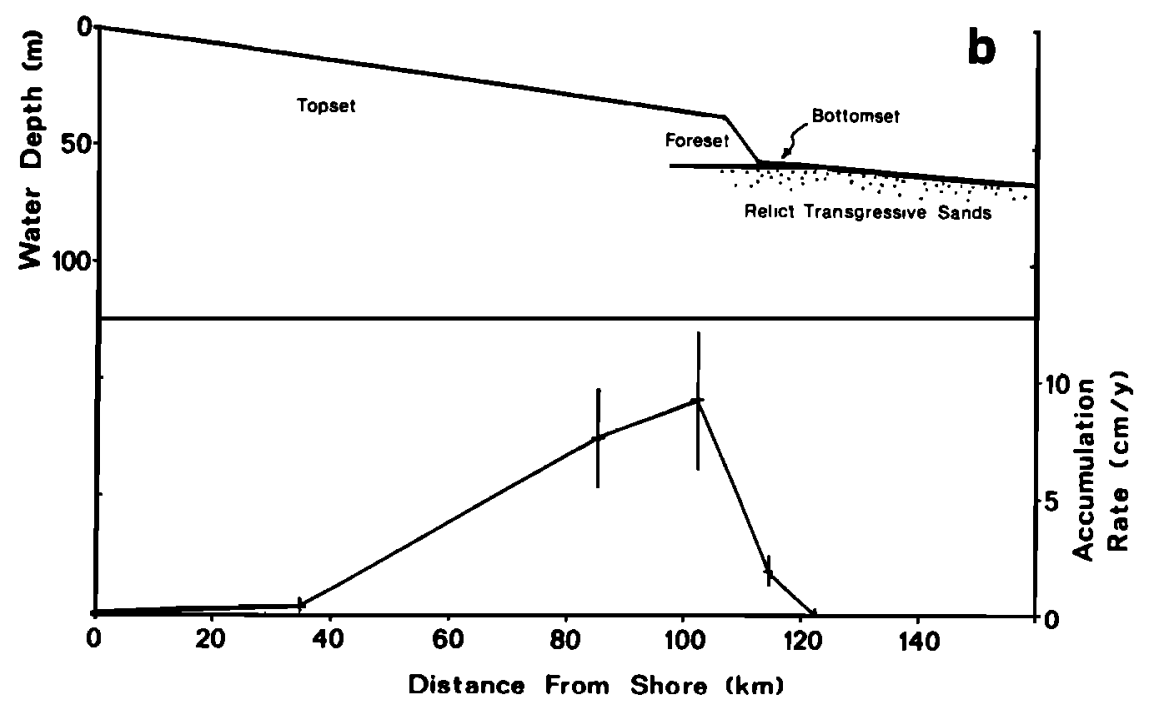

ACKNOWLEDGMENTS. The authors thank the National Science Foundation, in particular grants OCE-8812530 and OCE-9116035 (C.A.N.) and OCE-9017828 (L.D.W.), for support during preparation of this manuscript. This paper was originally suggested to the authors by Ken Brink, chairman of the Coastal Ocean Processes (CoOP) steering committee. Marine Sciences Research Center, SUNYStony Brook contribution 935; Virginia Institute of Marine Science, College of William and Mary, contribution 1791.

Alan D. Chave is the editor responsible for this paper. He thanks W. Rockwell Geyer and David E. Drake for providing careful technical reviews and Mary Fowler for a thoughtful cross-disciplinary review.

\section{REFERENCES}

Agrawal, Y. C., Long-term in situ measurement of particle size spectra and settling velocities in stress (abstract), Eos Trans. AGU, 72(41), Fall Meeting suppl., 241, 1991. 
Alexander, C. R., D. J. DeMaster, and C. A. Nittrouer, Sediment accumulation in a modern epicontinental-shelf setting: The Yellow Sea, Mar. Geol., 98, 51-72, 1991.

Alley, R. B., D. D. Blankenship, S. T. Rooney, and C. R. Bentley, Sedimentation beneath ice shelves-The view from ice stream B, Mar. Geol., 85, 101-120, 1989.

Amos, C. L., and J. T. Judge, Sediment transport on the eastern Canadian continental shelf, Cont. Shelf Res., 11, 1037-1068, 1991.

Amos, C. L., J. Grant, G. R. Daborn, and K. Black, Sea carousel-A benthic, annular flume, Estuarine Coastal Shelf Sci., 34, 557-577, 1992.

Anderson, J. B., C. F. Brake, and N. C. Myers, Sedimentation on the Ross Sea continental shelf, Antarctica, Mar. Geol., 57, 295-333, 1984.

Bailard, J. A., An energetics total load sediment transport model for a plain sloping beach, J. Geophys. Res., 86, 10,938-10,954, 1981.

Bailard, J. A., and D. L. Inman, An energetics bedload model for a plain sloping beach: Local transport, J. Geophys. Res., 86, 2035-2043, 1981.

Baines, P. G., Internal tides, internal waves and near-inertial motions, in Baroclinic Processes on Continental Shelves, Coastal Estuarine Sci., vol. 3, edited by C. N. K. Mooers, pp. 19-31, AGU, Washington, D. C., 1986.

Baker, E. T., Distribution and composition of suspended sediment in the bottom waters of the Washington continental shelf and slope, J. Sediment. Petrol., 43, 812-821, 1973.

Baker, E. T., Distribution, composition, and transport of suspended particulate matter in the vicinity of Willapa submarine canyon, Washington, Geol. Soc. Am. Bull., 87, 625-632, 1976.

Baker, E. T., and B. M. Hickey, Contemporary sedimentation processes in and around an active west coast submarine canyon, Mar. Geol, , 71, 15-34, 1986.

Battjes, J. A., Surf-zone dynamics, Annu. Rev. Fluid Mech., 20, 257-293, 1988.

Battjes, J. A., R. J. Sobey, and M. J. F. Stive, Nearshore circulation, in The Sea, vol. 9, Ocean Engineering Science, edited by B. LeMéhauté and D. M. Hanes, pp. 467-494, John Wiley, New York, 1990.

Beach, R. A., and R. W. Sternberg, Suspended sediment transport in the surf zone: Response to cross-shore infragravity motion, Mar. Geol., 80, 61-79, 1988.

Boczar-Karakiewicz, B., J. L. Bona, and B. Pelchat, Interaction of internal waves with the seabed on continental shelves, Cont. Shelf Res., 11, 1181-1197, 1991.

Boldrin, A., G. Bortoluzzi, F. Frascari, S. Guerzoni, and S. Rabitti, Recent deposits and suspended sediments off the Po Della Pila (Po River, main mouth) Italy, Mar. Geol., 79, 159-170, 1988.

Boldrin, A., M. Juracic, L. Menegazzo Vitturi, S. Rabitti, and G. Rampazzo, Sedimentation of riverborne material in a shallow shelf sea: Adige River, Adriatic Sea, Mar. Geol., 103, 473-485, 1992.

Borgeld, J. C., Holocene stratigraphy and sedimentation on the northern California continental shelf, $\mathrm{Ph} . \mathrm{D}$. dissertation, 177 pp., Univ. of Wash., Seattle, 1985.

Bornhold, B. D., Z.-S. Yang, G. H. Keller, D. B. Prior, W. J. Wiseman, Jr., Q. Wang, L. D. Wright, W. D. Xu, and Z. Y. Zhuang, Sedimentary framework of the modern Huanghe (Yellow River) delta, Geo Mar. Lett., 6, 77-83, 1986.

Brink, K. H., Coastal ocean physical processes, Rev. Geophys., 25, 204-216, 1987.

Brink, K. H. et al., Coastal Ocean Processes (CoOP): Results of an interdisciplinary workshop, Contrib. 7584, 51 pp., Woods Hole Oceanogr. Inst., Woods Hole, Mass., 1990.

Brink, K. H., et al., Coastal Ocean Processes (CoOP): A science prospectus, Rep. WH01-92-18, 88 pp., Woods Hole Oceanogr. Inst., Woods Hole, Mass., 1992.

Bruland, K. W., R. P. Franks, W. M. Blanding, and A. Soutar, Southern California interbasin trap calibration, Earth Planet. Sci. Lett., 53, 400-408, 1981.

Butman, B., M. Noble, and D. W. Fogler, Long-term observations of bottom current and bottom sediment movement on the Mid-Atlantic continental shelf, J. Geophys. Res., 84, 1187-1205, 1979.

Cacchione, D. A., and D. E. Drake, Shelf sediment transport, in The Sea, vol. 9, Ocean Engineering Science, edited by B. LeMéhauté and D. M. Hanes, pp. 729-774, John Wiley, New York, 1990.

Cacchione, D. A., and J. B. Southard, Incipient sediment movement by shoaling internal gravity waves, J. Geophys. Res., 79, 2237-2242, 1974.

Cacchione, D. A., D. E. Drake, W. D. Grant, and G. B. Tate, Rippled scour depressions on the inner continental shelf off central California, J. Sediment. Petrol., 54, 1280-1291, 1984.

Cacchione, D. A., M. E. Field, D. E. Drake, and G. B. Tate, Crescentic dunes on the inner continental shelf off northern California, Geology, 15, 1134-1137, $1987 a$.

Cacchione, D. A., W. D. Grant, D. E. Drake, and S. M. Glenn, Storm-dominated bottom boundary layer dynamics on the northern California continental shelf: Measurements and predictions, J. Geophys. Res., 92, 1817-1827, $1987 b$.

Cacchione, D. A., D. E. Drake, M. A. Losada, and R. Medina, Bottom-boundary-layer measurements on the continental shelf off the Ebro River, Spain, Mar. Geol., 95, 179-192, 1990.

Carpenter, R., M. L. Peterson, and J. T. Bennett, ${ }^{210} \mathrm{~Pb}-$ derived sediment accumulation and mixing rates for the Washington continental slope, Mar. Geol., 48, 135-164, 1982.

Carson, B., E. T. Baker, B. M. Hickey, C. A. Nittrouer, D. J. DeMaster, K. W. Thorbjarnarson, and G. W. Snyder, Modern sediment dispersal and accumulation in Quinault Submarine Canyon-A summary, Mar. Geol., 71, 1-13, 1986.

Chao, S.-Y., River-forced estuarine plumes, J. Phys. Oceanogr., 18, 72-88, 1988.

Chough, S. K., and D. C. Kim, Dispersal of fine-grained sediments in the southeastern Yellow Sea: A steady-state model, J. Sediment. Petrol., 51, 721-728, 1981

Christofferson, J. B., and I. G. Jonsson, Bed friction and dissipation in a combined current and wave motion, Ocean Eng., 12, 387-423, 1985.

Churchill, J. H., The effect of commercial trawling on sediment resuspension and transport over the Middle Atlantic Bight continental shelf, Cont. Shelf Res., 9, 841-864, 1989.

Churchill, J. H., P. E. Biscaye, and F. Aikman III, The character and motion of suspended particulate matter over the shelf edge and upper slope off Cape Cod, Cont. Shelf Res., 8, 789-809, 1988.

Clark, D. L., and A. Hanson, Central Arctic Ocean sediment texture: A key to ice transport mechanisms, in GlacialMarine Sedimentation, edited by B. F. Molnia, pp. 301330, Plenum, New York, 1983.

Coleman, J. M., Deltas: Processes of Deposition and Models for Exploration, 102 pp., Continuing Education Publication Co., Champaign, Ill., 1976.

CoPO Steering Committee, Coastal physical oceanography: Towards a national plan, Report of a meeting of the 
Coastal Physical Oceanography community, 118 pp., Woods Hole Oceanogr. Inst., Woods Hole, Mass., 1989.

Conley, D. C., and D. L. Inman, Field observations of the fluid-granular boundary layer under near-breaking waves, J. Geophys. Res., 97, 9631-9643, 1992.

Cowell, P. J., Australian "mega rip" study, Eos Trans. $A G U, 67,449,1986$.

Curtin, T. B., Physical observations in the plume region of the Amazon River during peak discharge, II, Water masses, Cont. Shelf Res., 6, 53-71, 1986.

Cutshall, N. H., I. L. Larsen, C. R. Olsen, C. A. Nittrouer, and D. J. DeMaster, Columbia River sediment in Quinault Canyon, Washington-Evidence from artificial radionuclides, Mar. Geol., 71, 125-136, 1986.

Davis, A. G., R. L. Soulsby, and H. L. King, A numerical model of the combined wave and current bottom boundary layer, J. Geophys. Res., 93, 491-508, 1988.

Dean, R. G. , and M. Perlin, Intercomparison of near-bottom kinematics by several wave theories and field and laboratory data, Coastal Eng., 9, 399-437, 1986.

DeMaster, D. J., B. A. McKee, C. A. Nittrouer, Qian Jiangchu, and Chen Guodong, Rates of sediment accumulation and particle reworking based on radiochemical measurements from continental shelf deposits in the East China Sea, Cont. Shelf Res., 4, 143-158, 1985.

Dias, J. M. A., and C. A. Nittrouer, Continental shelf sediments of northern Portugal, Cont. Shelf Res., 3, 147-165, 1984.

Dodd, N., J. Oltman-Shay, and E. B. Thorton, Shear instabilities in the longshore current: A comparison of observation and theory, J. Phys. Oceanogr., 22, 62-82, 1992.

Downing, J. P., R. W. Sternberg, and C. R. B. Lister, New instrumentation for the investigation of sediment suspension processes in the shallow marine environment, Mar. Geol., 42, 19-34, 1981.

Drake, D. E., and D. A. Cacchione, Seasonal variation in sediment transport on the Russian River shelf, California, Cont. Shelf Res., 4, 495-514, 1985.

Drake, D. E., and D. A. Cacchione, Suspended particulate matter along the Coastal Ocean Dynamics Experiment Central line during upwelling and relaxation events, $J$. Geophys. Res., 92, 1699-1707, 1987.

Drake, D. E., and D. A. Cacchione, Estimates of the suspended sediment reference concentration $\left(C_{\mathrm{a}}\right)$ and resuspension coefficient $\left(\gamma_{0}\right)$ from near-bed observations on the California shelf, Cont. Shelf Res., 9, 51-64, 1989.

Drake, D. E., and D. A. Cacchione, Wave-current interaction in the bottom boundary layer during storm and nonstorm conditions: Observations and model predictions, Cont. Shelf. Res., 12, 1331-1352, 1992.

Drake, D. E., R. L. Kolpack, and P. J. Fischer, Sediment transport on the Santa Barbara-Oxnard shelf, Santa Barbara Channel, California, in Shelf Sediment Transport: Process and Pattern, edited by D. J. P. Swift, D. B. Duane, and O. H. Pilkey, pp. 307-331, Van Nostrand Reinhold, New York, 1972.

Drake, D. E., D. A. Cacchione, and H. A. Karl, Bottom currents and sediment transport on San Pedro Shelf, California, J. Sediment. Petrol., 55, 15-28, 1985.

Drake, D. E., D. A. Cacchione, and W. D. Grant, Shear stress and bed roughness estimates for combined wave and current flows over a rippled bed, J. Geophys. Res., 97, 2319-2326, 1992.

Eckman, J. E., A. R. M. Nowell, and P. A. Jumars, Sediment destabilization by animal tubes, J. Mar. Res., 39, 361-374, 1981.

Eisma, D., and J. Kalf, Dispersal of Zaire River suspended matter in the estuary and the Angola Basin, Neth. J. Sea Res., 17, 385-411, 1984.
Fenton, J. D., Nonlinear wave theories, in The Sea, vol. 9, Ocean Engineering Science, edited by B. LeMéhauté and D. M. Hanes, pp. 3-26, John Wiley, New York, 1990.

Field, M. E., and P. S. Roy, Offshore transport and sandbody formation: Evidence from a steep, high-energy shoreface, southeastern Australia, J. Sediment. Petrol., 54, 1292-1302, 1984.

Forward, R. B., Responses of crustacean larvae to hydrostatic pressure: Behavioral basis of high barokinesis, Mar. Behav. Physiol., 17, 223-232, 1990.

Freeland, G. L., D. J. Stanley, D. J. P. Swift, and D. N. Lambert, The Hudson Shelf Valley: Its role in shelf sediment transport, Mar. Geol., 42, 399-427, 1981.

Frignani, M., and L. Langone, Accumulation rates and ${ }^{137} \mathrm{Cs}$ distribution in sediments off the Po River delta and the Emilia-Romagna coast (northwestern Adriatic Sea, Italy), Cont. Shelf Res., 11, 525-542, 1991.

Gagan, M. K., A. R. Chivas, and A. L. Herczeg, Shelf-wide erosion, deposition, and suspended sediment transport during cyclone Winifred, central Great Barrier Reef, Australia, J. Sediment. Petrol., 60, 456-470, 1990.

Garvine, R. W., A steady state model for buoyant surface plume hydrodynamics in coastal waters, Tellus, 34, 293306, 1982.

Garvine, R. W., Estuarine plumes and fronts in shelf waters: A layer model, J. Phys. Oceanogr., 17, 1877-1896, 1987.

Geyer, W. R., R. C. Beardsley, J. Candela, B. M. Castro, R. V. Legeckis, S. J. Lentz, R. Limeburner, L. B. Miranda, and J. H. Trowbridge, The physical oceanography of the Amazon outflow, Oceanography, 4, 8-14, 1991.

Glenn, S. M., and W. D. Grant, A suspended sediment stratification correction for combined wave and current flows, J. Geophys. Res., 92, 8244-8264, 1987.

Grant, W. D., and O. S. Madsen, Combined wave and current interaction with a rough bottom, $J$. Geophys. Res., 84, 1797-1808, 1979.

Grant, W. D., and O. S. Madsen, Movable bed roughness in oscillatory flow, J. Geophys. Res., 87, 469-481, 1982.

Grant, W. D., and O. S. Madsen, The continental shelf bottom boundary layer, Annu. Rev. Fluid Mech., 18, 265-305, 1986.

Grant, W. D., L. F. Boyer, and L. P. Sanford, The effects of bioturbation on the initiation of motion of intertidal sands, J. Mar. Sci., 40, 659-677, 1982.

Grant, W. D., A. J. Williams, and S. M. Glenn, Bottom stress estimates and their prediction on the northern California continental shelf during CODE-1: The importance of wave-current interaction, J. Phys. Oceanogr., 14, 506$527,1984$.

Green, M. O., J. M. Rees, and N. D. Pearson, Evidence for the influence of wave-current interaction in a tidal boundary layer, J. Geophys. Res., 95, 9629-9644, 1990.

Green, M. O., N. D. Pearson, M. R. Thomas, C. D. Rees, J. M. Rees, and T. R. E. Owen, Design of a data logger and instrument-mounting platform for seabed sediment transport research, Cont. Shelf Res., 12, 543-562, 1992.

Gross, M. G., and J. L. Nelson, Sediment movement on the continental shelf near Washington and Oregon, Science, $154,878-885,1966$.

Guza, R. T., and E. B. Thornton, Observations of surf beat, J. Geophys. Res., 90, 3161-3172, 1985.

Hallermeier, R. J., A profile zonation for seasonal sand beaches from wave climate, Coastal Eng., 4, 253-277, 1981.

Halper, F. B., and D. W. McGrail, Long-term measurements of near-bottom currents and suspended sediment concentration on the outer Texas-Louisiana continental shelf, Cont. Shelf Res., 8, 23-26, 1988.

Hanes, D. M., C. E. Vincent, D. A. Huntley, and T. L. 
Clarke, Acoustic measurement of suspended sediment concentration in the C2S2 experiment at Stanhope Lane, Prince Edward Island, Mar. Geol., 81, 185-196, 1988.

Harris, C. K., and P. L. Wiberg, Ripple geometry in wave dominated environments (abstract), Eos Trans. $A G U$, 72(44), Fall Meeting suppl., 245, 1991.

Harris, P. T., Sediments, bedforms and bedload transport pathways on the continental shelf adjacent to Torres Strait, Australia-Papua New Guinea, Cont. Shelf Res., 8 , 979-1003, 1988.

Harris, P. T., Reversal of subtidal dune asymmetries caused by seasonally reversing wind-driven currents in Torres Strait, northeastern Australia, Cont. Shelf Res., 11, 655662, 1991.

Harris, P. T., and M. B. Collins, Bedform distributions and sediment transport paths in the Bristol Channel and Severn Estuary, U.K., Mar. Geol., 62, 153-166, 1985.

Harris, P. T., and M. B. Collins, Estimation of annual bedload flux in a macrotidal estuary: Bristol Channel, $\mathrm{U}$. K., Mar. Geol., 83, 237-252, 1988.

Harris, P. T., and M. B. Collins, Sand transport in the Bristol Channel: Bedload parting zone or mutually evasive transport pathways?, Mar. Geol., 101, 209-216, 1991.

Harris, P. T., E. K. Baker, A. R. Cole, and S. A. Short, A preliminary study of sedimentation in the tidally dominated Fly River delta, Gulf of Papua, Cont. Shelf Res., 13, 441-472, 1993.

Heathershaw, A. D., Some observations of internal wave current fluctuations at the shelf-edge and their implications for sediment transport, Cont. Shelf Res., 4, 485493, 1985.

Heckel, P. H., Recognition of ancient shallow marine environments, in Recognition of Ancient Sedimentary Environments, edited by J. K. Rigby and W. K. Hamblin, Spec. Publ. Soc. Econ. Paleontol. Mineral., 16, 226-286, 1972.

Hedges, J. I., and D. C. Mann, The lignin geochemistry of marine sediments from the southern Washington coast, Geochim. Cosmochim. Acta, 43, 61-63, 1979.

Helfrich, K. R., Internal solitary wave breaking and run-up on a uniform slope, J. Fluid Mech., 243, 133-154, 1992.

Hickey, B., E. Baker, and N. Kachel, Suspended particle movement in and around Quinault Submarine Canyon, Mar. Geol., 71, 35-83, 1986.

Hill, P. R., and O. C. Nadeau, Storm-dominated sedimentation on the inner shelf of the Canadian Beaufort Sea, $J$. Sediment. Petrol., 59, 455-468, 1989.

Hill, P. R., S. M. Blasco, J. R. Harper, and D. B. Fissel, Sedimentation on the Canadian Beaufort Shelf, Cont. Shelf Res., 11, 821-841, 1991.

Hine, A. C., R. J. Wilber, J. M. Bane, A. C. Neumann, and K. R. Lorenson, Offbank transport of carbonate sands along open, leeward bank margins: Northern Bahamas, Mar. Geol., 42, 327-348, 1981.

Hoekstra, P., R. F. Nolting, and H. A. van der Sloot, Supply and dispersion of water and suspended matter of the rivers Solo and Brantas into the coastal waters of east Java, Indonesia, Neth. J. Sea Res., 23, 501-515, 1989.

Holloway, P. E., Internal hydraulic jumps and solitons at a shelf break region on the Australian north west shelf, $J$. Geophys. Res., 92, 5405-5416, 1987.

Holman, R., et al., Report on the state of nearshore processes research, Rep. OSU-CO-90-6, 25 pp., Oreg. State Univ., Corvallis, 1990.

Hoskin, C. M., J. K. Reed, and D. H. Mook, Production and off-bank transport of carbonate sediment, Black Rock, southwest Little Bahama Bank, Mar. Geol., 73, 125-144, 1986.
Huh, C.-A., L. F. Small, S. Niemnil, B. P. Finney, B. M. Hickey, N. B. Kachel, D. S. Gorsline, and P. M. Williams, Sedimentation dynamics in the Santa Monica-San Pedro Basin off Los Angeles: Radiochemical, sediment trap and transmissometer studies, Cont. Shelf Res., 10, 137-164, 1990.

Huntley, D. A., A modified inertial dissipation method for estimating seabed stresses at low Reynolds numbers, with application to wave/current boundary layer measurements, J. Phys. Oceanogr., 18, 339-346, 1988.

Huntley, D. A., and D. G. Hazen, Seabed stresses in combined wave and steady flow conditions on the Nova Scotia continental shelf: Field measurements and predictions, J. Phys. Oceanogr., 18, 347-362, 1988.

Huntley, D. A., R. T. Guza, and E. B. Thornton, Field observations of surf beat, J. Geophys. Res., 83, 1913$1920,1981$.

Huyer, A., Shelf circulation, in The Sea, vol. 9, Ocean Engineering Science, edited by B. LeMéhauté and D. M. Hanes, pp. 423-466, John Wiley, New York, 1990.

Inden, R. F., and C. L. Moore, Beach environment, in Carbonate Depositional Environments, edited by P. A. Scholle, D. G. Bebout, and C. H. Moore, pp. 211-265, American Association of Petroleum Geologists, Tulsa, Okla., 1983.

Inman, D. L., and C. E. Nordstrom, On the tectonic and morphologic classification of coasts, J. Geol., 79, 1-21, 1971.

Jacobs, S. S., Marine controls on modern sedimentation on the Antarctic continental shelf, Mar. Geol., 85, 121-153, 1989.

Jumars, P. A., Concepts in Biological Oceanography, An Interdisciplinary Primer, 348 pp., Oxford University Press, New York, 1993.

Kachel, N. B., and J. D. Smith, Geological impact of sediment transporting events on the Washington continental shelf, in Shelf Sands and Sandstones, edited by R. J. Knight and J. R. McLean, pp. 145-162, Canadian Society of Petroleum Geologists, Calgary, Alta., 1986.

Kachel, N. B., and J. D. Smith, Sediment transport and deposition on the Washington continental shelf, in Coastal Oceanography of Washington and Oregon, edited by M. R. Landry and B. M. Hickey, pp. 287-348, Elsevier, New York, 1989.

Kao, T. W., F.-H. Pan, and D. Renouard, Internal solitons on the pycnocline: Generation, propagation and shoaling and breaking over a slope, J. Fluid Mech., 159, 19-53, 1985.

Karlin, R., Sediment sources and clay mineral distributions off the Oregon coast, J. Sediment. Petrol., 50, 543-560, 1980.

Kenyon, N. H., and A. H. Stride, The tide-swept continental shelf sediments between the Shetland Islands and France, Sedimentology, 14, 159-173, 1970.

Kim, S. C., Inner continental shelf benthic boundary layer dynamics and suspended sediment transport, Ph.D. dissertation, Sch. of Mar. Sci., Va. Inst. of Mar. Sci., 159 pp., Coll. of William and Mary, Gloucester Point, 1990.

Kineke, G. C., R. W. Sternberg, D. A. Cacchione, K. Kranck, and D. E. Drake, Distribution and characteristics of suspended sediment on the Amazon Shelf, Oceanography, 4, 21-26, 1991.

Knebel, H. J., J. C. Kelley, and J. T. Whetten, Clay minerals of the Columbia River: A qualitative, quantitative, and statistical evaluation, J. Sediment. Petrol., 38, 600-611, 1968.

Krause, N. C., and K. Horikawa, Nearshore sediment transport, in The Sea, vol. 9, Ocean Engineering Science, 
edited by B. LeMéhauté and D. M. Hanes, pp. 775-814, John Wiley, New York, 1990.

Kuehl, S. A., D. J. DeMaster, and C. A. Nittrouer, Nature of sediment accumulation on the Amazon continental shelf, Cont. Shelf Res., 6, 209-225, 1986.

Kuehl, S. A., T. M. Hariu, and W. S. Moore, Shelf sedimentation off the Ganges-Brahmaputra river system: Evidence for sediment bypassing to the Bengal fan, Geology, 17, 1132-1135, 1989.

Largier, J. L., Internal shelf tides and wind-driven motions in deepening the surface mixed layer, Ph.D. thesis, 192 pp., Univ. of Cape Town, Rondebosch, South Africa, 1987.

Lee, H. J., and S. K. Chough, Sediment distribution, dispersal and budget in the Yellow Sea, Mar. Geol., 87, 195-205, 1989.

Lentz, S., A. Clarke, J. Eckman, R. Guza, M. Freilich, R. Sternberg, K. Thompson, J. Trowbridge and D. Wright, Inner-shelf exchange: A coastal physical oceanography workshop, 23 pp., Woods Hole Oceanogr. Inst., Woods Hole, Mass., 1990.

Lentz, S. J., and J. H. Trowbridge, The bottom boundary layer over the northern California shelf, J. Phys. Ocean$o g r ., 21,1186-1201,1991$.

List, J. H., A model for the generation of two-dimensional surf beat, J. Geophys. Res., 97, 5623-5635, 1992.

Longuet-Higgins, M. S., and R. W. Stewart, Radiation and mass transport in gravity waves, with application to surf beats, J. Fluid Mech., 13, 481-504, 1962.

Longuet-Higgins, M. S., and R. W. Stewart, Radiation stresses in water waves: A physical discussion with applications, Deep Sea Res., 11, 529-562, 1964.

Lowe, R. L., D. L. Inman, and T. G. Drake, A bedload sensor for wave and current regimes (abstract), Eos Trans. $A G U, 72(44)$, Fall Meeting suppl., 230, 1991.

Lynch, J. F., Y. C. Agrawal, and C. R. Sherwood, Instrumental measures of particle size and settling velocity in STRESS (abstract), Eos Trans. AGU, 72(44), Fall Meeting suppl., 241, 1991.

Lyne, V. D., B. Butman, and W. D. Grant, Sediment movement along the U.S. east coast continental shelf, I, Estimates of bottom stress using the Grant-Madsen-Glenn model and near-bottom wave and current measurements, Cont. Shelf Res., 10, 397-428, 1990a.

Lyne, V. D., B. Butman, and W. D. Grant, Sediment movement along the U.S. east coast continental shelf, II, Modeling suspended sediment concentration and transport rate during storms, Cont. Shelf Res., 10, 429-460, $1990 b$.

Maa, J. P.-Y., T. W. Shannon, C. Li, and C. H. Lee, In situ measurements of the critical bed shear stress for erosion, in Proceedings of International Symposium on Environmental Hydraulics, edited by J. H. W. Lee and Y. K. Cheung, vol. 1, pp. 627-632, A. A. Balkema, Rotterdam, Netherlands, 1991.

Madsen, O. S., Combined wave and current flows over a rippled bottom: Theoretical considerations (abstract), Eos Trans. AGU, 72(44), Fall Meeting, Program and Abstracts, 229, 1991.

Madsen, O. S., L. D. Wright, J. D. Boon, and T. A. Chisholm, Wind stress, bed roughness, and sediment suspension on the inner shelf during an extreme storm event, Cont. Shelf Res., 13, 1303-1324, 1993.

Malikides, M., P. T. Harris, and P. M. Tate, Sediment transport and flow over sandwaves in a non-rectilinear tidal environment: Bass Strait, Australia, Cont. Shelf Res., 9, 203-221, 1989.

Maldonado, A., et al., Sedimentation on the Valencia con- tinental shelf: Preliminary results, Cont. Shelf Res., 2, 195-211, 1983.

Malouta, D. N., D. S. Gorsline, and S. E. Thornton, Processes and rates of recent (Holocene) basin filling in an active transform margin: Santa Monica Basin, California continental borderland, J. Sediment. Petrol., 51, $1077-$ 1095, 1981.

Massel, S. R., Hydrodynamics of Coastal Zones, 338 pp., Elsevier Science, New York, 1989.

McCave, I. N., Transport and escape of fine-grained sediment from shelf areas, in Shelf Sediment Transport: Process and Pattern, edited by D. J. P. Swift, D. B. Duane, and O. H. Pilkey, pp. 225-248, Van Nostrand Reinhold, New York, 1972.

McGrail, D. W., and M. Carnes, Shelfedge dynamics and the nepheloid layer in the northwestern Gulf of Mexico, in The Shelfbreak: Critical Interface on Continental Margins, edited by D. J. Stanley and G. T. Moore, Spec. Publ. Soc. Econ. Paleontol. Mineral., 33, 251-264, 1983.

McKee, B. A., D. J. DeMaster, and C. A. Nittrouer, The use of ${ }^{234} \mathrm{Th} /{ }^{238} \mathrm{U}$ disequilibrium to examine the fate of particle reactive species on the Yangtze continental shelf: Particle scavenging and removal to the seabed, Earth Planet. Sci. Lett., 68, 431-442, 1984.

Meade, R. H., Landward transport of bottom sediments in estuaries of the Atlantic coastal plain, J. Sediment. Petrol., 39, 222-234, 1969.

Meade, R. H., P. L. Sachs, F. T. Manheim, J. C. Hathaway, and D. W. Spencer, Sources of suspended matter in waters of the Middle Atlantic Bight, J. Sediment. Petrol., 45, 171-188, 1975.

Mehta, A. J. (Ed.), Estuarine Cohesive Sediment Dynamics, 473 pp., Springer-Verlag, New York, 1986.

Mehta, A. J., and E. J. Hayter (Eds.), High concentration cohesive sediment transport, J. Coastal Res., special issue 5, 230 pp., 1989.

Milliman, J. D., and R. H. Meade, World-wide delivery of river sediment to the oceans, J. Geol., 91, 1-21, 1983.

Milliman, J. D., R. C. Beardsley, Yang Zuo-Sheng, and R. Limeburner, Modern Huanghe-derived muds on the outer shelf of the East China Sea: Identification and potential transport mechanisms, Cont. Shelf Res., 4, 175-188, 1985.

Milliman, J. D., Y. Qin, M. E. Ren, and Y. Saito, Man's influence on the erosion and transport of sediment by Asian rivers, The Yellow River (Huanghe) example, $J$. Geol., 95, 751-762, 1987.

Mitchum, G. T., and A. J. Clarke, The frictional nearshore response to forcing by synoptic scale winds, J. Phys. Oceanogr., 16, 934-946, 1986.

Monaco, A., P. Biscaye, J. Soyer, R. Pecklington, and S. Heussner, Particle fluxes and ecosystem response on a continental margin: The 1985-1988 Mediterranean ECOMARGE experiment, Cont. Shelf Res., 10, 9-11, 1990.

Mooers, C. N. K. (Ed.), Baroclinic Processes on Continental Shelves, Coastal Estuarine Sci., vol. 3, 144 pp., AGU, Washington, D. C., 1986.

Moore, C. H., E. A. Graham, and L. S. Land, Sediment transport and dispersal across the deep fore-reef and island slope ( $-55 \mathrm{~m}$ to $-305 \mathrm{~m}$ ), Discovery Bay, Jamaica, J. Sediment. Petrol., 46, 174-187, 1976.

Morton, R. A., Formation of storm deposits by wind-forced currents in the Gulf of Mexico and the North Sea, Spec. Publ. Int. Assoc. Sedimentol., 5, 385-396, 1981.

Nelson, C. H., Modern shallow-water graded sand layers from storm surges, Bering Shelf: A mimic of Bouma sequences and turbidite systems, J. Sediment. Petrol. $52,537-545,1982$.

Nichols, M. M., and R. B. Biggs, Estuaries, in Coastal 
Sedimentary Environments, edited by R. A. Davis, Jr., pp. 77-186, Springer-Verlag, New York, 1985.

Niedoroda, A. W., and D. J. P. Swift, Maintenance of the shoreface by wave orbital currents and mean flow: Observations from the Long Island coast, Geophys. Res. Lett., 8, 337-348, 1981.

Niedoroda, A. W., D. J. P. Swift, T. S. Hopkins, and C. M. $\mathrm{Ma}$, Shoreface morphodynamics on wave-dominated coasts, Mar. Geol., 60, 331-354, 1984.

Nielsen, P., Some basic concepts of wave sediment transport, Ser. Pap. 20, 160 pp., Inst. of Hydrodyn. and Hydraul. Eng., Tech. Univ. Denmark, Lyngby, 1979.

Nielsen, P., Dynamics and geometry of wave generated ripples, J. Geophys. Res., 86, 6467-6472, 1981.

Nielsen, P., Analysis of natural waves by local approximations, J. Waterway, Port, Coastal Ocean Eng., 115, 384396, 1989.

Nielsen, P., Coastal Bottom Boundary Layers and Sediment Transport, 324 pp., World Scientific, River Edge, N. J., 1992.

Niino, H., and K. O. Emery, Sediments of shallow portions of East China Sea and South China Sea, Geol. Soc. Am. Bull., 72, 731-762, 1961.

Nittrouer, C. A., The process of detrital sediment accumulation in a continental shelf environment: An examination of the Washington shelf, Ph.D. dissertation, 243 pp., Univ. of Wash., Seattle, 1978.

Nittrouer, C. A., and R. W. Sternberg, The formation of sedimentary strata in an allochthonous shelf environment: The Washington continental shelf, Mar. Geol., 42, 201-232, 1981.

Nittrouer, C. A., R. W. Sternberg, R. Carpenter, and J. T. Bennett, The use of ${ }^{210} \mathrm{~Pb}$ geochronology as a sedimentological tool: Application to the Washington continental shelf, Mar. Geol., 31, 297-316, 1979.

Nittrouer, C. A., S. A. Kuehl, D. J. DeMaster, and R. O. Kowsmann, The deltaic nature of Amazon shelf sedimentation, Geol. Soc. Am. Bull., 97, 444-458, 1986.

Nittrouer, C. A., B. E. Bergenback, D. J. DeMaster, and S. A. Kuehl, Accumulation of mixed carbonate and siliciclastic muds on the continental shelf of eastern Spain, in Carbonate-Clastic Transitions, edited by L. J. Doyle and H. H. Roberts, pp. 251-269, Elsevier Science, New York, 1988.

Nowell, A. R. M., and R. A. Wheatcroft, Sediment transport events on slopes and shelves (STRESS), in Geology and Geophysics Program Summary for FY 91, pp. 95-96, Office of the Chief of Naval Research, Arlington, Va., 1992.

Nowell, A. R. M., I. N. McCave, and C. D. Hollister, Contributions of HEBBLE to understanding marine sedimentation, Mar. Geol., 66, 397-409, 1985.

Nowell, A. R. M., P. A. Jumars, and J. B. Southard, Responses of intertidal macrofauna to ripple migration in a laboratory racetrack flume, in Ecology of Marine Deposit Feeders, edited by G. R. Lopez, G. L. Taghon, and J. S. Levinton, pp. 247-268, Springer-Verlag, New York, 1989.

Okihiro, M., R. T. Guza, and R. J. Seymour, Infragravity bound waves in shallow and deep water (abstract), Eos Trans. $A G U, 72(44)$, Fall Meeting suppl., 253, 1991.

Oltman-Shay, J. M., A climatological study of infragravity waves in 8 meters depth (abstract), Eos Trans. AGU, 72(44), Fall Meeting suppl., 253, 1991.

Oltman-Shay, J., and R. T. Guza, Infragravity edge wave observations on two California beaches, J. Phys. Oceanogr., 117, 644-663, 1987.

Osborne, P. D., and B. Greenwood, Frequency dependent cross-shore suspended sediment transport, 1, A nonbarred shoreface, Mar. Geol., 106, 1-24, $1992 a$.

Osborne, P. D., and B. Greenwood, Frequency dependent cross-shore suspended sediment transport, 2, A barred shoreface, Mar. Geol., 106, 25-52, $1992 b$.

Pak, H., and J. R. V. Zaneveld, Bottom nepheloid layers and bottom mixed layers observed on the continental shelf off Oregon, J. Geophys. Res., 82, 3921-3931, 1977.

Pak, H. J., R. V. Zaneveld, and R. W. Spinrad, Vertical distribution of suspended particulate matter in the Zaire river, estuary and plume, Neth.J. Sea Res., 17, 412-425, 1984.

Palanques, A., and P. E. Biscaye, Patterns and controls of the suspended matter distribution over the shelf and upper slope south of New England, Cont. Shelf Res., 12, 577-600, 1992.

Palanques, A., and D. E. Drake, Distribution and dispersal of suspended particulate matter on the Ebro continental shelf, northwestern Mediterranean Sea, Mar. Geol., 95, 193-206, 1990.

Palanques, A., F. Plana, and A. Maldonado, Recent influence of man on the Ebro margin sedimentation system, northwestern Mediterranean Sea, Mar. Geol., 95, 247263, 1990.

Park, Y. A., and B. K. Khim, Origin and dispersal of recent clay minerals in the Yellow Sea, Mar. Geol., 104, 205213, 1992.

Park, Y.-A., S.-C. Kim, and J.-H. Choi, The distribution and transportation of fine-grained sediments on the inner continental shelf off the Keum River estuary, Korea, Cont. Shelf Res., 5, 499-519, 1986.

Parkinson, R. W., Geologic evidence of net onshore sand transport throughout the Holocene marine transgression, southwest Florida, Mar. Geol., 96, 269-277, 1991.

Pietrafesa, L. J., Shelfbreak circulation, fronts and physical oceanography: East and west coast perspectives, in The Shelfbreak: Critical Interface on Continental Margins, edited by D. J. Stanley and G. T. Moore, Spec. Publ. Soc. Econ. Paleontol. Mineral., 33, 233-250, 1983.

Pilkey, O. H., and M. E. Field, Onshore transportation of continental shelf sediment: Atlantic southeastern United States, in Shelf Sediment Transport, edited by D. J. P. Swift, D. B. Duane, and O. H. Pilkey, pp. 429-446, Van Nostrand Reinhold, New York, 1972.

Pineda, J., Predictable upwelling and the shoreward transport of planktonic larvae by internal tidal bores, Science, 253, 548-551, 1991.

Prahl, F. G., Chemical evidence of differential particle dispersal in the southern Washington coastal environment, Geochim. Cosmochim. Acta, 49, 2533-2539, 1985.

Pujos, M., and O. Javelaud, Depositional facies of a mud shelf between the Sinu river and the Darien Gulf (Caribbean coast of Colombia): Environmental factors that control its sedimentation and origin of deposits, Cont. Shelf Res., 11, 601-623, 1991.

Reid, D. E., and J. B. Anderson, Hazards to Antarctic exploration and production, in Antarctica as an Exploration Frontier, edited by B. St. John, AAPG Stud. Geol., 33, 31-45, 1990.

Rhoads, D. C., Organism-sediment relations on the muddy sea floor, Oceanogr. Mar. Biol., 12, 263-300, 1974.

Ridge, M. J. H., and B. Carson, Sediment transport on the Washington continental shelf: Estimates of dispersal rates from Mount St. Helens ash, Cont. Shelf Res., 7, $759-772,1987$.

Roelvink, J. A., and M. J. Stive, Bar-generating cross-shore flow mechanisms on a beach, J. Geophys. Res., 94, 47854800, 1988. 
Royer, T. C., Coastal fresh water discharge in the northeast Pacific, J. Geophys. Res., 87, 2017-2021, 1982.

Sahl, L. E., W. J. Merrell, D. W. McGrail, and J. A. Webb, Transport of mud on continental shelves: Evidence from the Texas shelf, Mar. Geol., 76, 33-43, 1987.

Schwalbach, J. R., and D. S. Gorsline, Holocene sediment budgets for the basins of the California continental borderland, J. Sediment. Petrol., 55, 829-842, 1985.

Segall, M. P., and S. A. Kuehl, Sedimentary processes on the Bengal continental shelf as revealed by clay-size mineralogy, Cont. Shelf Res., 12, 517-541, 1992.

Seymour, R. J., Autosuspending turbidity flows, in The Sea, vol. 9, Ocean Engineering Science, edited by B. LeMéhauté and D. M. Hanes, pp. 919-940, John Wiley, New York, 1990.

Shanks, A. L., Surface slicks associated with tidally forced internal waves may transport pelagic larvae of benthic invertebrates and fishes shoreward, Mar. Ecol. Prog. Ser., 13, 311-315, 1983.

Shanks, A. L., Further support for the hypothesis that internal waves can cause shoreward transport of larval invertebrates and fish, Fish. Bull., 86, 703-714, 1988.

Shanks, A. L., and W. G. Wright, Internal-wave-mediated shoreward transport of cyprids, megalopae, and gammarids and correlated longshore differences in the settling rate of intertidal barnacles, J. Exp. Mar. Biol. Ecol., 114, $1-13,1987$.

Sherwood, C. R., Y. C. Agrawal, and J. F. Lynch, Suspended sediment concentration profile measurements in STRESS (abstract), Eos Trans. AGU, 72(44), Fall Meeting suppl., 241, 1991.

Shi, N. C., and L. H. Larsen, Reverse sediment transport induced by amplitude modulated waves, Mar. Geol., 54, 181-200, 1984.

Shinn, E. A., Tidal flat environment, in Carbonate Depositional Environments, edited by P. A. Scholle, D. G. Bebout, and C. H. Moore, pp. 172-210, American Association of Petroleum Geologists, Tulsa, Okla., 1983.

Simpson, J. H., and I. D. James, Coastal and estuarine fronts, in Baroclinic Processes on Continental Shelves, Coastal Estuarine Sci., vol. 3, edited by C. N. K. Mooers, pp. 63-93, AGU, Washington, D. C., 1986.

Sleath, J. F. A., Turbulent oscillatory flow over rough beds, J. Fluid Mech., 182, 369-409, 1987.

Sleath, J. F. A., Seabed boundary layers, in The Sea, vol. 9, Ocean Engineering Science, edited by B. LeMéhauté and D. M. Hanes, pp. 693-728, John Wiley, New York, 1990.

Smith, J. D., Geomorphology of a sand ridge, J. Geol., 77, 39-55, 1969.

Smith, J. D., Modeling of sediment transport on continental shelves, in The Sea, vol. 6, Marine Modeling, edited by E. D. Goldberg et al., pp. 539-576, Wiley-Interscience, New York, 1977.

Smith, J. D., and T. S. Hopkins, Sediment transport on the continental shelf off of Washington and Oregon in light of recent current measurements, in Shelf Sediment Transport, edited by D. J. P. Swift, D. B. Duane, and O. H. Pilkey, pp. 143-180, Van Nostrand Reinhold, New York, 1972.

Smith, J. D., and S. R. McLean, Spatially averaged flow over a wavy surface, J. Geophys. Res., 82, 1735-1746, 1977.

Smith, R. L., A comparison of the structure and variability of the flow field in three coastal upwelling regions: Oregon, northwest Africa, and Peru, in Coastal Upwelling, Coastal Estuarine Sci., vol. 1, edited by F. A. Richards, pp. 107-118, AGU, Washington, D. C., 1981.

Snedden, J. W., and D. Nummedal, Origin and geometry of storm-deposited sand beds in modern sediments of the
Texas continental shelf, Spec, Publ. Int. Assoc. Sedimentol., 14, 283-308, 1991.

Snedden, J. W., D. Nummedal, and A. F. Amos, Storm- and fair-weather combined flow on the central Texas continental shelf, J. Sediment. Petrol., 58, 580-595, 1988.

Soulsby, R. L., Tidal-current boundary layers, in The Sea, vol. 9, Ocean Engineering Science, edited by B. LeMéhauté and D. M. Hanes, pp. 523-566, John Wiley, New York, 1990.

Sternberg, R. W., and D. A. McManus, Implications of sediment dispersal from long-term, bottom-current measurements on the continental shelf of Washington, in Shelf Sediment Transport, edited by D. J. P. Swift, D. B. Duane, and O. H. Pilkey, pp. 181-194, Van Nostrand Reinhold, New York, 1972.

Sternberg, R. W., R. V. Johnson II, D. A. Cacchione, and D. E. Drake, An instrument system for monitoring and sampling suspended sediment in the benthic boundary layer, Mar. Geol., 71, 187-199, 1986.

Stride, A. H., Current-swept sea floors near the southern half of Great Britain, Q. J. Geol. Soc. London, 119, 175-199, 1963.

Stride, A. H., Indications of long term episodic suspension transport of sand across the Norfolk Banks, North Sea, Mar. Geol., 79, 55-64, 1988.

Stride, A. H., and R. H. Belderson, A reassessment of sand transport paths in the Bristol Channel and their regional significance, Mar. Geol., 92, 227-236, 1990.

Stride, A. H., and R. H. Belderson, Sand transport in the Bristol Channel east of Bull Point and Worms Head: A bed-load parting model with some indications of mutually evasive sand transport paths, Mar. Geol., 101, 203-207, 1991.

Svendsen, I. A., Mass flux and undertow in a surf zone, Coastal Eng., 8, 347-365, 1984.

Swift, D. J. P., A. W. Niedoroda, C. E. Vincent, and T. S. Hopkins, Barrier island evolution, Middle Atlantic Shelf, U.S.A., I, Shoreface dynamics, Mar. Geol., 63, 331-361, 1985.

Thorbjarnarson, K. W., C. A. Nittrouer, and D. J. DeMaster, Accumulation of modern sediment in Quinault Submarine Canyon, Mar. Geol., 71, 107-124, 1986.

Trowbridge, J., and O. S. Madsen, Turbulent wave boundary layers, 1, Model formulation and first-order solution, J. Geophys. Res., 97, 7989-7998, 1984a.

Trowbridge, J., and O. S. Madsen, Turbulent wave boundary layers, 2 , Second-order theory and mass transport, $J$. Geophys. Res., 89, 7999-8007, $1984 b$.

Uncles, R. J. (Ed.), Dynamics of turbid coastal environments, Cont. Shelf Res., 7, 1267-1493, 1987.

Vincent, C. E., and M. O. Green, Field measurements of the suspended sand concentration profiles and fluxes, and of the resuspension coefficient $\gamma_{0}$ over a rippled bed, $J$. Geophys. Res., 95, 11,591-11,602, 1990.

Vincent, C. E., D. J. P. Swift, and B. Hillard, Sediment transport in the New York Bight, North American Atlantic shelf, Mar. Geol., 42, 369-398, 1981.

Walsh, J. J., P. E. Biscaye, and G. T. Csanady, The 19831984 Shelf Edge Exchange Processes (SEEP)-I experiment: Hypothesis and highlights, Cont. Shelf Res., 8, 435-456, 1988.

Wells, D. R., Beach equilibrium and second-order wave theory, J. Geophys. Res., 72, 497-504, 1967.

Wiberg, P. L., The dynamics of sand transport on the inner continental shelf, in Geology and Geophysics Program Summary for FY 1991, pp. 106-108, Office of the Chief of Naval Research, Arlington, Va., 1992.

Wiberg, P. L., and J. M. Nelson, Unidirectional flow over 
asymmetric and symmetric ripples, J. Geophys. Res., 97, 12,745-12,761, 1992.

Wiberg, P. L., and J. D. Smith, A comparison of field data and theoretical models for wave-current interactions at the bed on the continental shelf, Cont. Shelf Res., 2, 147-162, 1983.

Wiberg, P. L., and J. D. Smith, Model for calculating bedload transport of sediment, J. Hydraul. Eng., 115, 101123, 1989.

Williams, A. J., III, Bottom turbulence in STRESS, in Geology and Geophysics Program Summary for FY 1991, pp. 109-111, Office of the Chief of Naval Research, Arlington, Va., 1992.

Williams, A. J., T. F. Gross, and D. Cacchione, Cross shelf structure of wave and current events in the bottom boundary layer of STRESS (abstract), Eos Trans. AGU, 72(44), Fall Meeting suppl., 241, 1991.

Wright, L. D., Dispersal and deposition of river sediments in coastal seas: Models from Asia and the tropics, Neth.J. Sea Res., 23, 493-500, 1989.

Wright, L. D., Micromorphodynamics of the inner continental shelf: A Middle Atlantic Bight case study, J. Coastal Res., spec. issue 15, 93-124, 1993.

Wright, L. D., R. T. Guza, and A. D. Short, Dynamics of a high energy dissipative surf zone, Mar. Geol., 45, 41-62, 1982.

Wright, L. D., J. D. Boon, M. O. Green, and J. H. List, Response of the mid shoreface of the Southern MidAtlantic Bight to a "northeaster," Geo. Mar. Lett., 6, 153-160, 1986.
Wright, L. D., W. J. Wiseman, Z.-S. Yang, B. D. Bornhold, G. H. Keller, D. B. Prior, and J. N. Suhayda, Processes of marine dispersal and deposition of suspended silts off the modern mouth of the Huanghe (Yellow River), Cont. Shelf Res., 10, 1-40, 1990.

Wright, L. D., J. D. Boon, S. C. Kim, and J. H. List, Modes of cross-shore sediment transport on the shoreface of the Middle Atlantic Bight, Mar. Geol., 96, 19-51, 1991a.

Wright, L. D., J. D. Boon, J.-P. Xu, and O. S. Madsen, Wave-current flows over a rippled bottom: Field observations on the inner shelf (abstract), Eos Trans. AGU, Fall Meeting suppl., Program and Abstracts, 229, $1991 b$.

Wright, L. D., J. D. Boon, J.-P. Xu, and S. C. Kim, The bottom boundary layer of the bay stem plains environment of lower Chesapeake Bay, Estuarine Coastal Shelf Sci., 35, 17-36, 1992.

Wright, L. D., J. P. Xu, and O. S. Madsen, Across-shelf benthic transports on the inner shelf of the Middle Atlantic Bight during the "Halloween Storm" of 1991, Mar. Geol., in press, 1994.

Young, R. A., and J. B. Southard, Erosion of fine-grained marine sediments: Sea floor and laboratory experiments, Bull. Geol. Soc. Am., 89, 663-672, 1978.

C. A. Nittrouer, Marine Sciences Research Center, State University of New York, Stony Brook, NY 11794.

L. D. Wright, Virginia Institute of Marine Science, College of William and Mary, Gloucester Point, VA 23062. 